\title{
Palaeozoic and Mesozoic igneous activity in the Netherlands: a tectonomagmatic review
}

\author{
W. Sissingh \\ Department of Earth Sciences, Utrecht University, Budapestlaan 4, \\ 3384 CD Utrecht, \\ The Netherlands; e-mail: w.sissingh@geo.uu.nl.
}

Manuscript submitted: June 2003; accepted: May 2004

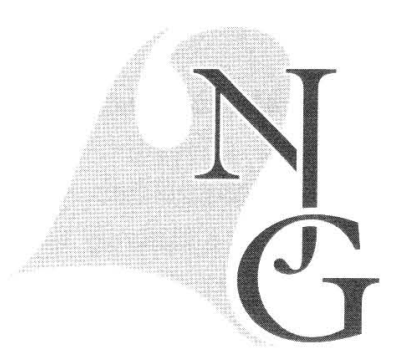

\begin{abstract}
To date, igneous rocks, either intrusive or extrusive, have been encountered in the Palaeozoic-Mesozoic sedimentary series of the Netherlands in some 65 exploration and production wells. Following 17 new isotopic K/Ar age determinations of the recovered rock material (amounting to a total of 28 isotopic ages from 21 different wells), analysis of the stratigraphic distribution of the penetrated igneous rock bodies showed that the timing of their emplacement was importantly controlled by orogenic phases involving intra-plate wrench and rift tectonics. Magmatism coincided with the Acadian (Late Devonian), Sudetian (early Late Carboniferous), Saalian (Early Permian), Early Kimmerian (late Late Triassic), Mid-Kimmerian (Late Jurassic), Late Kimmerian (earliest Cretaceous) and Austrian (latest Early Cretaceous) tectonic phases. This synchroneity presumably reflects (broadly) coeval structural reorganizations of respectively the Baltica/Fennoscandinavia-Laurentia/Greenland, Laurussia-Gondwana, African-Eurasia and Greenland/Rockall-Eurasia plate assemblies. Through their concomitant changes of the intra-plate tectonic stress regime, inter-plate motions induced intra-plate tectonism and magmatism. These plate-tectonics related events determined the tectonomagmatic history of the Dutch realm by inducing the formation of localized centres, as well as isolated spot occurrences, of igneous activity. Some of these centres were active at (about) the same time. At a number of centres igneous activity re-occurred after a long period of time.
\end{abstract}

Key words: Palaeozoic, Mesozoic, the Netherlands, magmatism, volcanism, plate tectonics, orogenic phases, tectonomagmatic history

\section{Introduction}

Igneous rocks have been encountered in the Dutch onshore and offshore regions in some 65 exploration and production wells since Tesch (1925) published the finding of a 'diabase' in well Corle, the country's first oil discovery well located between Winterswijk and Lichtenvoorde in the eastern Netherlands. The principal objective of the present paper is to review the stratigraphic distribution of all these occurrences of igneous rock and to outline, in conjunction with data on volcanigenic sediments, their relation to the structural history of the Netherlands during the Palaeozoic and Mesozoic.

The present paper is based on an intensive search in industrial well files for information on igneous activity in the Dutch geological domain. The study was originally carried out in 1985 when the author was assigned by Shell Internationale Petroleum Maatschappij (SIPM, The Hague) to the Nederlandse Aardolie Maatschappij (NAM, Assen). During the project, material from 17 igneous rock bodies was (re)discovered in NAM's core storage facility and radiometrically dated by the ZWO Laboratory of 
Isotope Geology (Amsterdam) to supplement the limited available data (Sissingh, 1986). Though detailed petrographic descriptions have been published (e.g. Tomkieff \& Tesch, 1931; van Voorthuysen, 1944; van der Sijp, 1953; Dixon et al., 1981, Kuijper, 1991), the drilled igneous rocks warrant further, for instance geochemical, investigation. So far, the rocks have been mostly classed as basalt, basanite, diabase, dolerite or gabbro (see van Bergen \& Sissingh; in press, for a review). Their qualifications concerning an intrusive or extrusive mode of emplacement should be considered with care, as interpretations are sometimes based on poor or conflicting information.

\section{General tectonic setting}

Though comparatively limited in size, the Dutch territory is geologically very complex below its Cenozoic sedimentary cover. An eventful pre-Tertiary succession of geological events governed by alternating compressional and extensional tectonic phases affected the area, sometimes including very drastic modification of uplift and subsidence patterns. Faults and other tectonic features were repeatedly re-activated and redefined in concomitance with newly established regional stress regimes. Resultant regional unconformities of the Palaeozoic and Mesozoic sedimentary series testify to the widespread nature of the tectonic phases (Ziegler, 1990; van Adrichem Boogaert \& Kouwe, 1993)

In Palaeozoic and Mesozoic time, the Netherlands domain was situated between the Mid North Sea and Ringkøbing Fyn highs in the north and the LondonBrabant and Rhenish massifs in the south. Within the Variscan Foreland Basin, tectonic structuration became increasingly prominent due to the northwards progradation of the Variscan thrust-and-fold belt during the Late Carboniferous, which included the Sudetian and Asturian orogenic phases. From the latest Carboniferous-earliest Permian onwards, initial Step Graben and Central Graben systems transected the northerly North Sea and Ringkøbing-Fyn highs along N-S oriented fractures. In the centre of the Dutch Variscan Foreland Basin a NW-SE trending Texel-IJsselmeer High occurred (Rijkers \& Geluk, 1996) within a regional tectonic framework characterized by similarly striking principal faults. In association with numerous smaller tectonic elements, which, altogether, evolved as a coherent but highly dynamic mosaic of crustal blocks, the major positive structural elements determined and influenced the general structuration and contemporary sedimentary history in the Netherlands until late in the Cretaceous. They delineated the Palaeozoic and Mesozoic basin systems as relatively stable and persistent highs. The Early Permian Saalian orogeny determined to a large extent the epeirogenic closure of the Variscan foredeep and the successive development the E-W trending, evaporitic Southern Permian Basin (Glennie, 1986; van Wees et al., 2000). Successively, the latest Triassic to earliest Cretaceous phases of Kimmerian orogenic deformation culminated with the Middle to Late Jurassic emplacement of a continental to marine, N-S and NW-SE striking rift system across the Dutch onand offshore region (van Wijhe, 1987).

Halokinesis of the Zechstein evaporites complicated since the Middle Triassic the geological architecture of the northern part of the Dutch realm by the formation of large salt walls and salt domes flanked by sizable rimsynclines. Following a period of relative tectonic quiescence, widespread inversion of basins belonging to the Late Jurassic-earliest Cretaceous graben system prevailed during the late part of the Late Cretaceous and the Early Tertiary in response to the Subhercynian, Laramide and Pyrenean orogenic pulses (van Wijhe, 1987; Dronkers \& Mrozek, 1991). The associated N-S trending crustal compression rejuvenated pre-existing fracture systems that previously controlled basin subsidence. Reflecting the full-scale Alpine continental collision of the Apulian, Iberian and European plates, the involved intra-plate compressions caused bounding normal faults of basins to reverse their sense of motion and locally induced overthrusting along and near basin margins. The positive movements induced partial erosion of sedimentary fills and covers of the inverted basins, particularly along their longitudinal axes. Contemporaneously, the Mid North Sea and Ringkøbing Fyn highs in the north and the London-Brabant Massif in the south lost their delimiting significance by subsidence. Like the intermediate basinal realm, the longlived positive structures were eventually buried by a thick series of mainly Late Cretaceous chalk and Tertiary clays, possibly as a consequence of post-rift thermal subsidence that lead to a large marine sag basin.

\section{Occurrences of igneous rock}

The stratigraphic distribution of igneous rock bodies, including the dolerite intrusion described by Kuijper (1991) from the Upper Carboniferous of well G17-2 and other discoveries made after the original study (Sissingh, 1986), and the occurrence of volcanogenic sediments is summarized in the Figures 1 to 3 and in the Appendix. The areal distribution is reviewed in the Figures 4 to 7 . Reference is made to van Adrichem Boogaert \& Kouwe (1993) for detailed stratigraphic 
information and for descriptions of structural elements. The chronostratigraphic calibration of the isotopic ages is primary based on the numerical time scale of Gradstein \& Ogg (1996).

\section{Crystalline basement}

Crystalline basement rock has so far only been penetrated in well A17-1 (Figs 1 and 4). The rock consists of an altered Late Caledonian (Early Palaeozoic) biotite monzo-granite for which a minimum $\mathrm{Ar} / \mathrm{Ar}$ age of $346 \pm 7 \mathrm{Ma}$ (earliest Carboniferous) has been determined (Appendix; Frost et al., 1981; Ziegler, 1990).

\section{Devonian}

The basement rock penetrated in well A17-1 is overlain by clastics of the Old Red Group (Late Devonian). In the Famennian sequence of the Buchan Formation it contains an Acadian rhyolite (quartz-porphyry or rhyodacite) with an age of $341 \pm 30 \mathrm{Ma}$ that is associated with weathered volcanics (Fig. 2). The igneous rocks occur in the formation interbedded with sediments. Supported by the presence of relict spherulitic textures in rims around quartz phenocrysts, these features indicate that the A17-1 felsic rocks are volcanics, which extruded in a number of flows. Sedimentary reworking is apparent from the occurrence of tiny grains of felsic rocks, invaded and surrounded by rims of Buchan claystone (pers. comm. R.P. Kuijper).

\section{Carboniferous}

Within the Limburg Group most of the generally gabbroid or doleritic intrusive rocks occur in the Elbow Spit High area and eastern Netherlands (Figs 2 and 4).

The stratigraphic position (Fig. 1) and the K/Ar age (Appendix) of the igneous body in well Dwingelo-2 (Thiadens, 1963) suggest that it is a Westphalian intrusion. On seismic it forms a marker sill several kilometers in length.

Judging from their radiometric ages (Appendix), the igneous rocks in the wells Baarlo-1, E18-2, Hardenberg-2, De Wijk-7 (at $2690.5 \mathrm{~m}$; Thiadens, 1963) and Steenwijkerwold-1 are best interpreted as Early Permian in age, whereas those in the wells Wanneperveen-1 and Winterswijk-1 are (Late) Triassic. However, the stratigraphic position, soft-sediment deformation at the base and evidence for submergence and weathering at the top of the basaltic bed in well Steenwijkerwold-1 indicate an extrusive mode of emplacement (pers. comm. J.M. van
Buggenum and D.G. den Hartog Jager, NAM), rendering its K/Ar dating rejectable. The basalts and dolerites of well Wanneperveen-1 (Kimpe, 1953) presumably occur as dykes. The gabbros encountered at greater depth may represent a comparatively large intrusive body, probably a laccolith or a thick sill (cf. Kimpe, 1953). Alternatively, they may merely represent a dyke of large thickness (pers. comm. R.P. Kuijper). The well is at the centre of a pronounced positive Bouguer gravity anomaly which, however, does not show on the geomagnetic map (Atlas van Nederland, 1963-1977). The intrusions of the wells E6-1 and De Wijk-7 (at $2456.1 \mathrm{~m}$ ) are Jurassic in age (Appendix).

A large intrusive body has been detected from coalification anomalies in Late Carboniferous strata in wells situated in the Ems estuary and adjacent southern parts of the German North Sea (Kettel, 1983). The apparent intrusion of this Groningen High (Fig. 1) has not been reached in any well. The shape of the anomaly coincides with regional structural trends and a positive areomagnetic anomaly. The age of the intrusion has been assumed to be coincident with the Jurassic-Cretaceous boundary (appprox.) if not Early Permian (Kettel, 1983).

Near the Roer Valley Graben and Peel Horst, east of Vlodrop (Prov. of Limburg), the undated 'Erkelenz Laccolith' occurs underneath anthracite-bearing Upper Westphalian A (Teichmüller \& Teichmüller, 1971; Bredewout, 1997).

Stratified extrusive rock has been identified in well Nagele-1. The beds occur with a compatible K/Ar age (Appendix) in the transitional Visean-Namurian sequence (Figs 1 to 3 ). They are interpreted as basaltic lava flows. Proof for coeval intrusive rocks is lacking and, because such rocks would be best developed in and directly around a volcanic vent, there is consequently no evidence for a centralized volcanic cone. This interpretation is supported by geophysics, since there are no gravity and geomagnetic indications for a volcanic centre such as associated with the Zuidwal Volcano (see below). The apparent absence of tuff may indicate that the lava erupted during relatively non-violent volcanic activity, when magma with a low content of volatiles erupted and typically only minor amounts of pyroclastic ejecta are produced. Therefore, the lava could have erupted from a fissure zone rather than from a centralized vent.

\section{Permian}

Rotliegend volcanics occur in the northernmost offshore and the eastern onshore Netherlands (Figs 1, 5 $\& 6$ ). Detailed petrographic data on their occurrence 


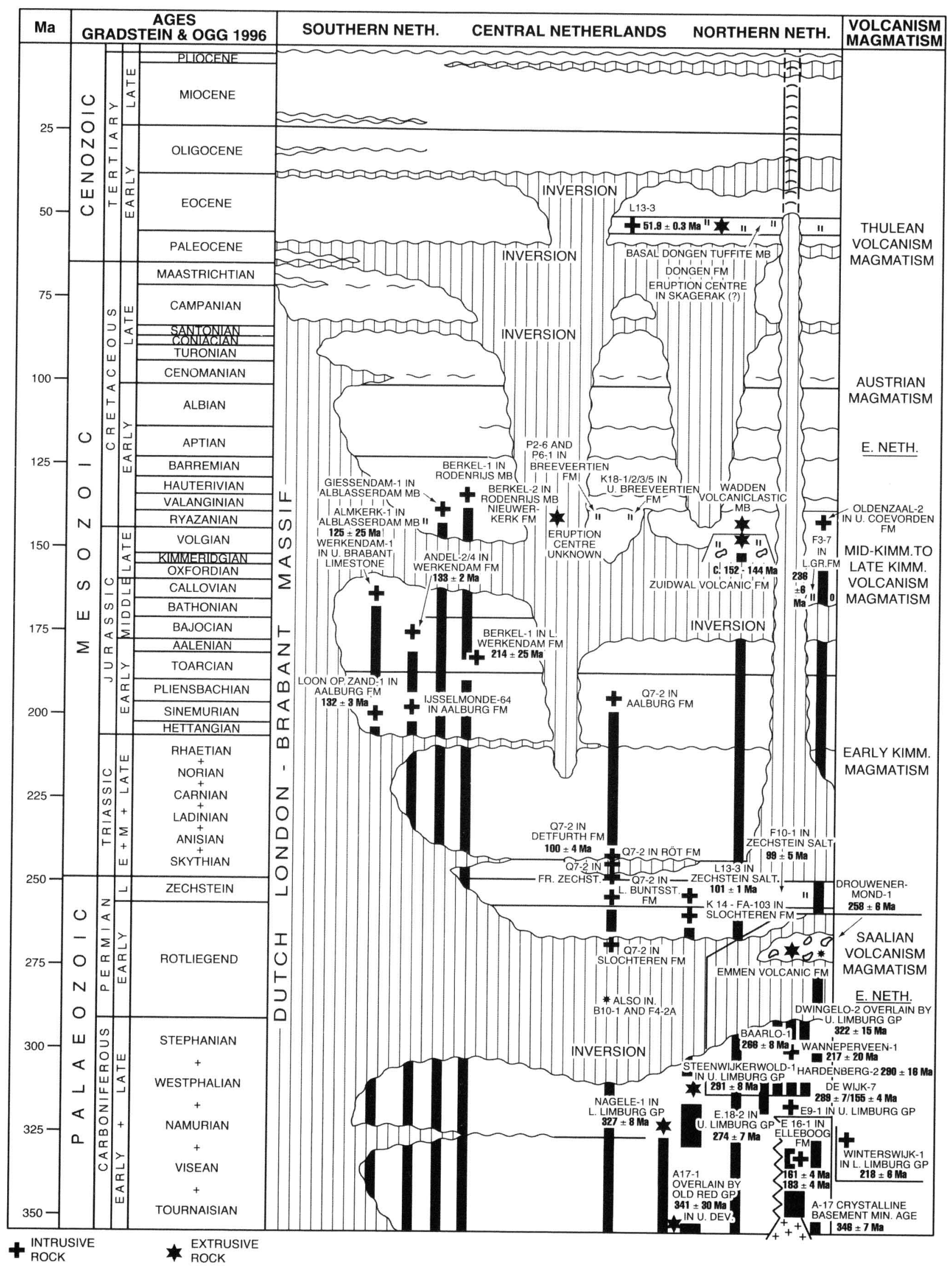

Fig. 1 Stratigraphic summary of intrusive and extrusive igneous rock in the subsurface of the on- and offshore Netherlands (see also Figs 2, 4, $5 \& 6)$. 


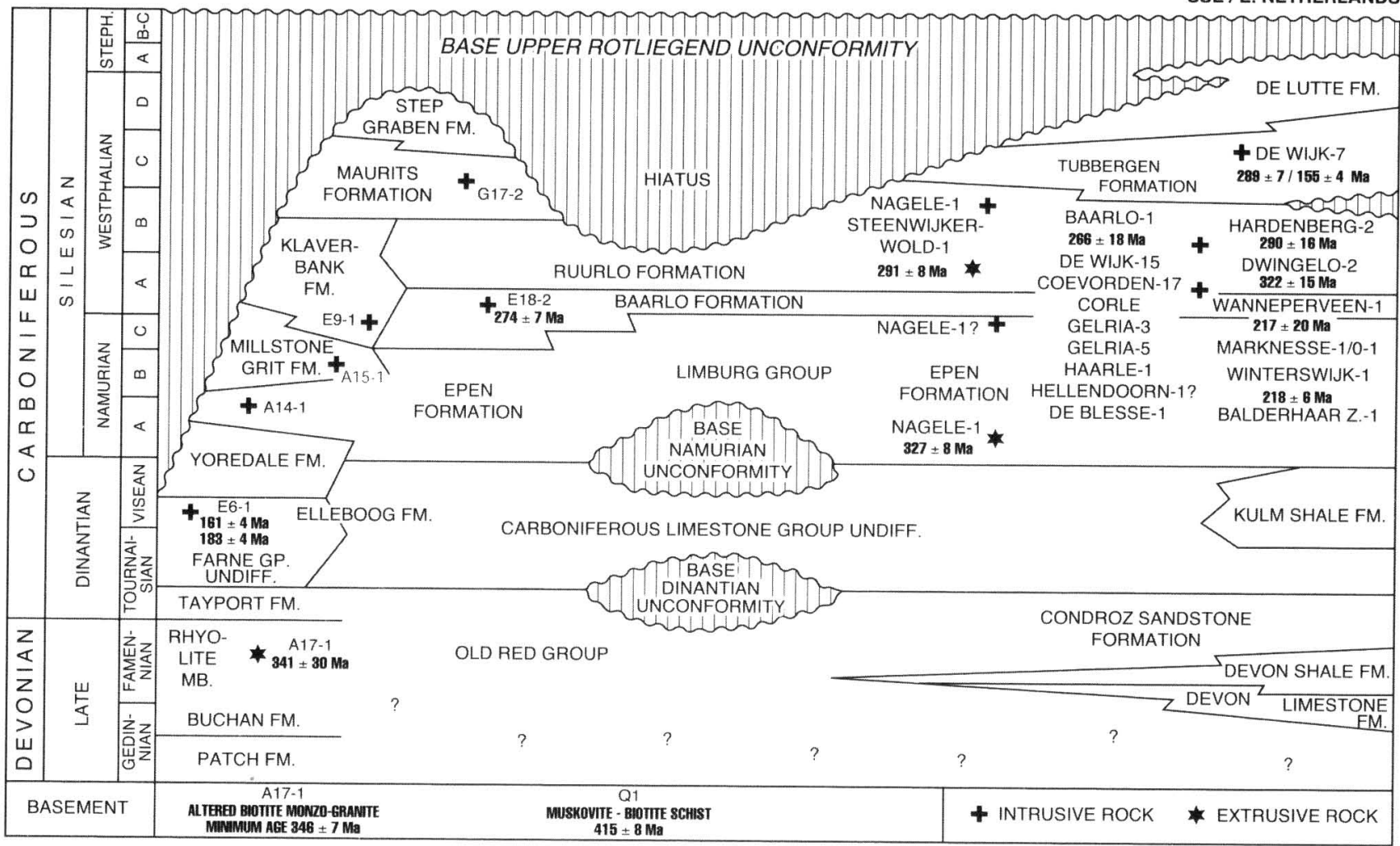

Fig. 2 Stratigraphic distribution of igneous rock in the pre-Permian of the Netherlands north of the London-Brabant Massif, from the Elbow Spit High in the northern most offshore sector to the eastermost onshore domain.

in wells on the Ringkøbing-Fyn High in the German sector have been given by Dixon et al. (1981). Their sample material showed the presence of two groups of volcanics, each with a consistent petrographic and geochemical character. One group consists of aphyric and slightly porphyritic, highly feldspatic basalts, some of which could be described as hawaiites. The other group includes devitrified, fine-grained porphyritic rhyolites or rhyodacites. A sub-volcanic igneous suite of felsic rocks (gabbros) and mafic rocks (micro-granodiorites) has also been encountered in well A15-1 (Fig. 2). In view of the dominance of plagioclase over alkali-feldspar the Rotliegend (sub-)volcanic rocks in well F4-2A belong to the latter group. After emplacement, they have been strongly altered at low temperatures (pers. comm. R.P. Kuijper). The bimodal igneous suite of the Ringkøbing-Fyn High area indicates a partial melting of infracrustal rock material (generating the felsic components) under influence of advective heat transfer from mantlederived rock material (generating the mafic components).

The bimodal association is echoed in northern Germany. Spilitized basaltic rock types and their penecontemporaneous products of erosion typify the Rotliegend volcanics in the German Ems Low region
(Eckhardt, 1968, 1979; Marx et al., 1995) and in the Emmen Volcanic Formation in the adjacent Dutch area. In the latter area a K/Ar age has been obtained from the pre-Zechstein volcanic sequence in well Drouwenermond-1. It agrees (best) with a late Early Permian age (Appendix).

Intrusives have been found in the Slochteren Sandstone of the wells K14-FA-103 and Q7-2 (Figs 1 and 5). They have not been dated, but the one in well Q7-2 may be contemporaneous with the late Albian/Cenomanian intrusion in the Triassic Detfurth Formation (see below).

Intrusive rocks in the Zechstein salt series are present in the wells F10-1 and L13-3, and in the Fringe Zechstein deposits of well Q7-2 (Figs 1 and 5). They are all assumed to be late Albian/Cenomanian in age (Fig. 3). In well L13-3 a partial overprint event of Early Eocene (Ypresian) age (about $52 \mathrm{Ma}$ ) has also been identified (Dixon et al., 1981).

\section{Triassic}

In well Q7-2 intrusions occur not only in the Permian sequence, but also in the earliest Scythian Main Claystone Member of the Lower Buntsandstein Formation, in the Middle Triassic Detfurth and Röt 


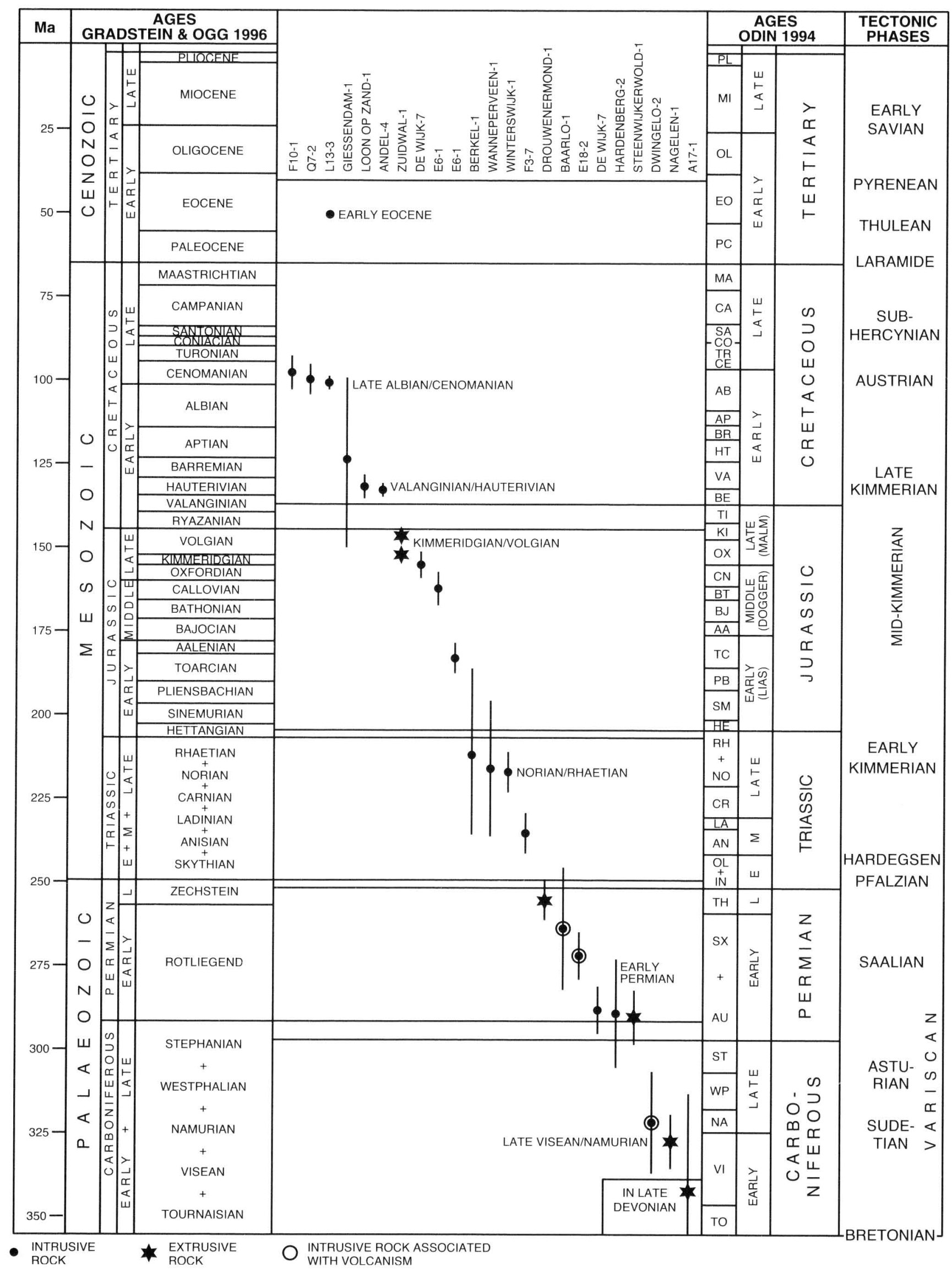

Fig. 3 Chronostratigraphic distribution of igneous activity in the Netherlands after the geological time-scales of Odin (1994) and Gradstein \& Ogg (1996), in conjunction with the generally recognized tectonic phases of the Paleozoic, Mesozoic and Cenozoic. 


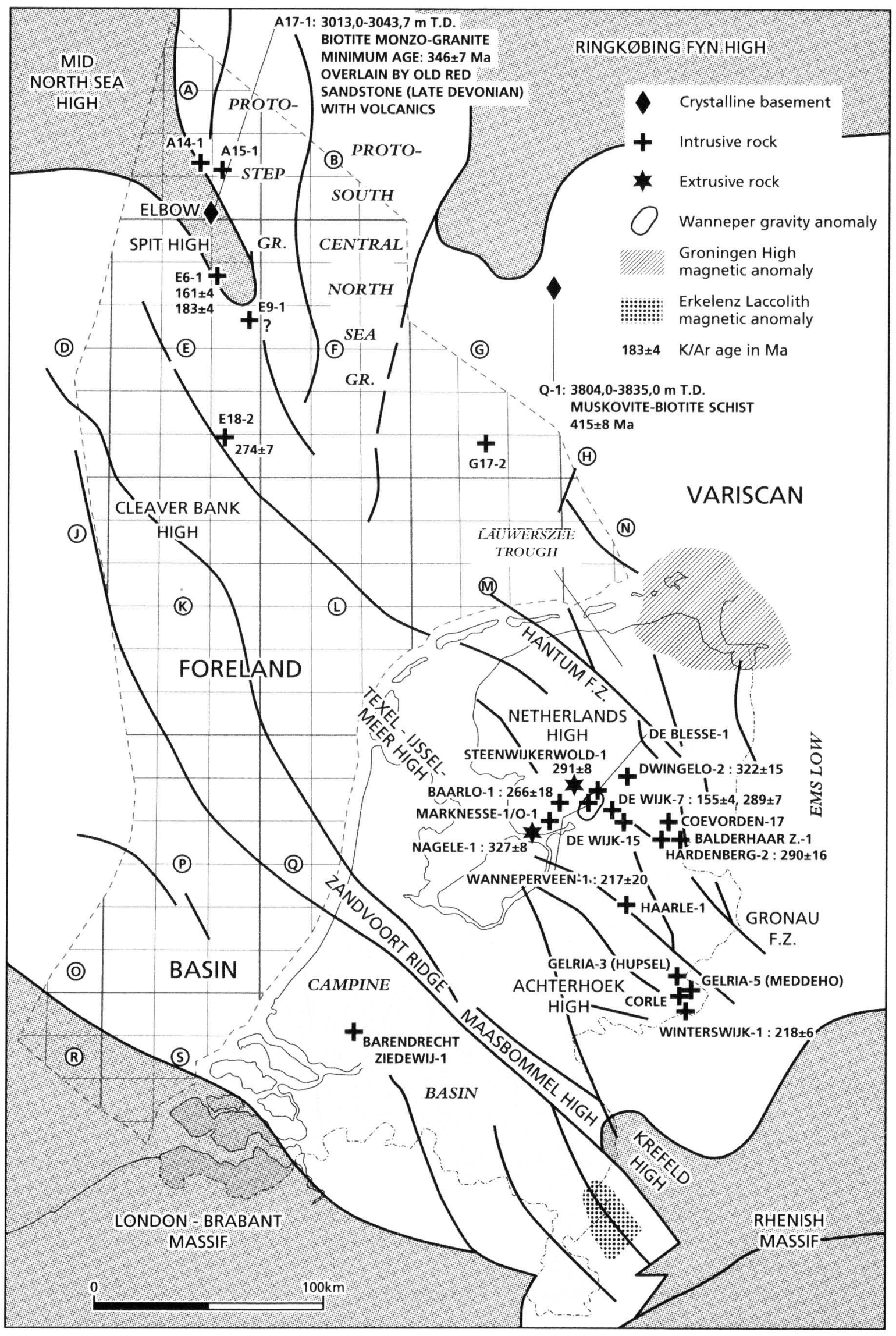

Fig. 4 Areal distribution of igneous rocks in the pre-Permian, in conjunction with late Variscan structural elements. N.B.: Only few well have been drilled to the Carboniferous in the southern part of the Dutch offshore. Those which reached the Carboniferous penetrated only a limited succession of rocks. 
formations, and in the Early Jurassic Aalburg Formation (Figs 1 \& 5). They are assumed to be Late Albian/Cenomanian in age, although only a single one (Figs 3 \& 5) in the Detfurth Formation (Appendix) has been dated as such (Dixon et al., 1981). Intrusions have also been found in the Triassic of the wells P6-B1 (lamprophyre), P6-10 (volcanic breccia), P9-8, (olivine basalt) and P12-8 (clinopyroxene crystals in cutting samples; Fig. 5; pers. comm. R.P. Kuijper). Their age is unknown.

\section{Lower and Middle Jurassic}

Intrusions have been found in the Altena rock sequence of the West Netherlands Basin (Figs 1 \& 5). The intrusive rocks in well Berkel-1 (van der Sijp, 1953; Dixon et al., 1981) occur in the Aalenian/ Bajocian Lower Werkendam Member of the Werkendam Formation above the Toarcian Posidonia Shale. Consequently, they are post-Early Jurassic in age, with which its isotopic age of $214 \pm 25 \mathrm{Ma}$ (Appendix) does nor fit. Perhaps, it is coeval with those in the wells Andel-4 and Loon op Zand-1 which have been dated as Early Cretaceous (Valanginian/Hauterivian) (Fig. 3; see also Dixon et al., 1981). Speculatively, the intrusive rock body in the Aalburg Formation of well Q7-2 is regarded to be late Albian/Cenomanian in age (see above).

\section{Upper Jurassic and early Lower Cretaceous}

In well Giessendam-1 an Early Cretaceous intrusive rock (Fig. 3) occurs in the Kimmeridgian/OxfordianBarremian Alblasserdam Member of the Nieuwerkerk Formation. Well Berkel-2 contains an (undated) intrusion in the Late Valanginian-Early Hauterivian Rodenrijs Claystone Member of the same formation (Figs. $1 \&$ 5). The Giessendam and Berkel-2 intrusions are possibly of a similar Early Cretaceous age as those in the Altena Group of the same region (see above).

In the eastern Netherlands well Oldenzaal-2 (van Voorthuysen, 1944) contains an (undated) 'diabase' intrusion in the Ryazanian-earliest Valanginian Upper Coevorden Member of the Coevorden Formation (Figs 1 \& 5; van Voorthuysen, 1944).

An extrusive agglomerate including brecciated trachytic and phonolitic rocks and leucite-bearing lavas constitutes the Zuidwal Volcanic Formation of the Vlieland Basin (Fig. 1; Harrison et al., 1979; Dixon et al., 1981; Perrot \& van der Poel, 1987; Herngreen et al., 1991). This volcanic eruption centre (Fig. 5) shows up clearly on gravimetric and magnetometric maps (e.g. Veldkamp, 1951; van Weelden, 1957) and coincides with a temperature anomaly at depth (van Montfrans \& Mot, 1984). It has been dated as $152 \pm 3$, 145 and $144 \pm 1 \mathrm{Ma}$ (Appendix) and would therefore have been active during Kimmeridgian-Volgian or Oxfordian-Kimmeridgian time (Fig. 3).

\section{Occurrences of volcanogenic sediment}

Recognition of penecontemporaneous volcanogenic minerals in sediments may be very difficult and highly subjective where primary textures have been obliterated by post-depositional alteration. Volcanic glass is particularly unstable and readily altered through processes such as devitrification, hydration and chemical attack to clay. Moreover, the finest (farthest-travelled) airborne volcanic ash is more likely to be completely argillised. These features may explain why, to date, the initially widespread tuffaceous materials at Eocene and older stratigraphic levels have only been recognized in a few wells. The most definitive criterium for the identification of penecontemporaneous volcanogenics is of course isotopic age determinations of pyroclasts in agreement with the (bio)stratigraphic age of their containing sediments, as illustrated by the volcanic igneous rocks in the wells Drouwenermond1 (Early Permian) and Nagele-1 (near ViseanNamurian boundary). In addition to in-place solid volcanic rocks, sediments with volcanogenic materials have been identified in Upper Carboniferous, Lower Cretaceous and Early Tertiary sequences (Figs $1 \& 7$; see also Fig. 9).

\section{Upper Carboniferous}

Research in adjacent Germany indicates that the Limburg Group contains widely traceable kaolinitecoal-tonstein with tuffaceous pyroclastic material (c. $310 \mathrm{Ma}$ ) that evidences the occurrence of explosive volcanism outside the Dutch region during the Westphalian (Lippolt et al., 1984; Delcambre, 1987). From the Netherlands these (marker) horizons are known from the coalfields in Limburg (Kimpe, 1966). They are not recognizable by means of routine electric logging in hydrocarbon exploration wells. As an exception, a tuff layer $(5 \mathrm{~cm})$ has been identified in well Hoogenweg-1 (southeast of well Wanneperveen-2; at $3134 \mathrm{~m}$; attributed to the Hagen-1 tonstein of early Westphalian age).

\section{Cretaceous}

The domal structure of the Zuidwal Volcano in the Vlieland Basin (of which the Zuidwal-1 gas discovery well drilled the volcanic pipe for hundreds of metres) 


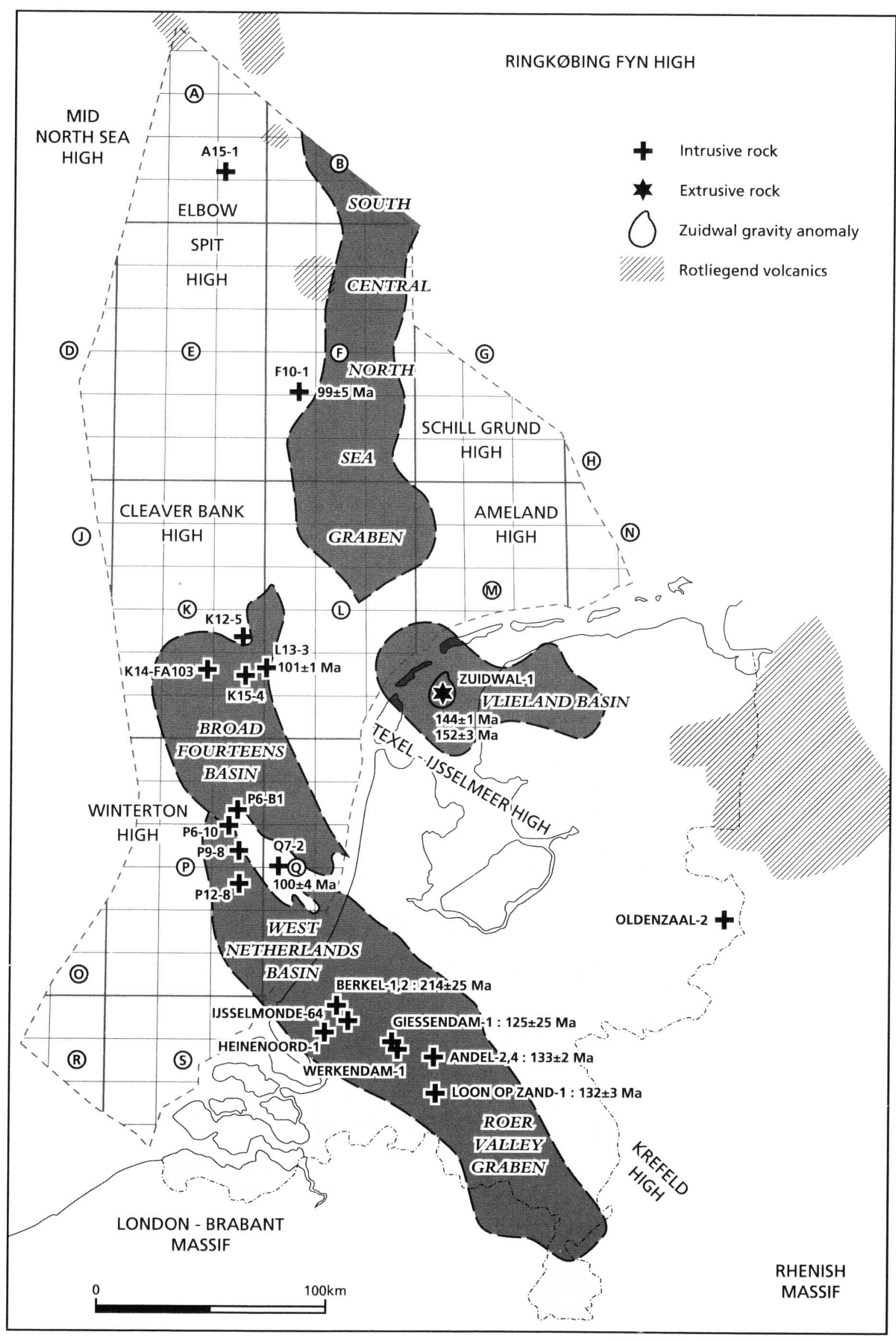

Fig. 5 Areal distribution of igneous rocks in the post-Carboniferous, in conjunction with late Kimmerian structural elements. 


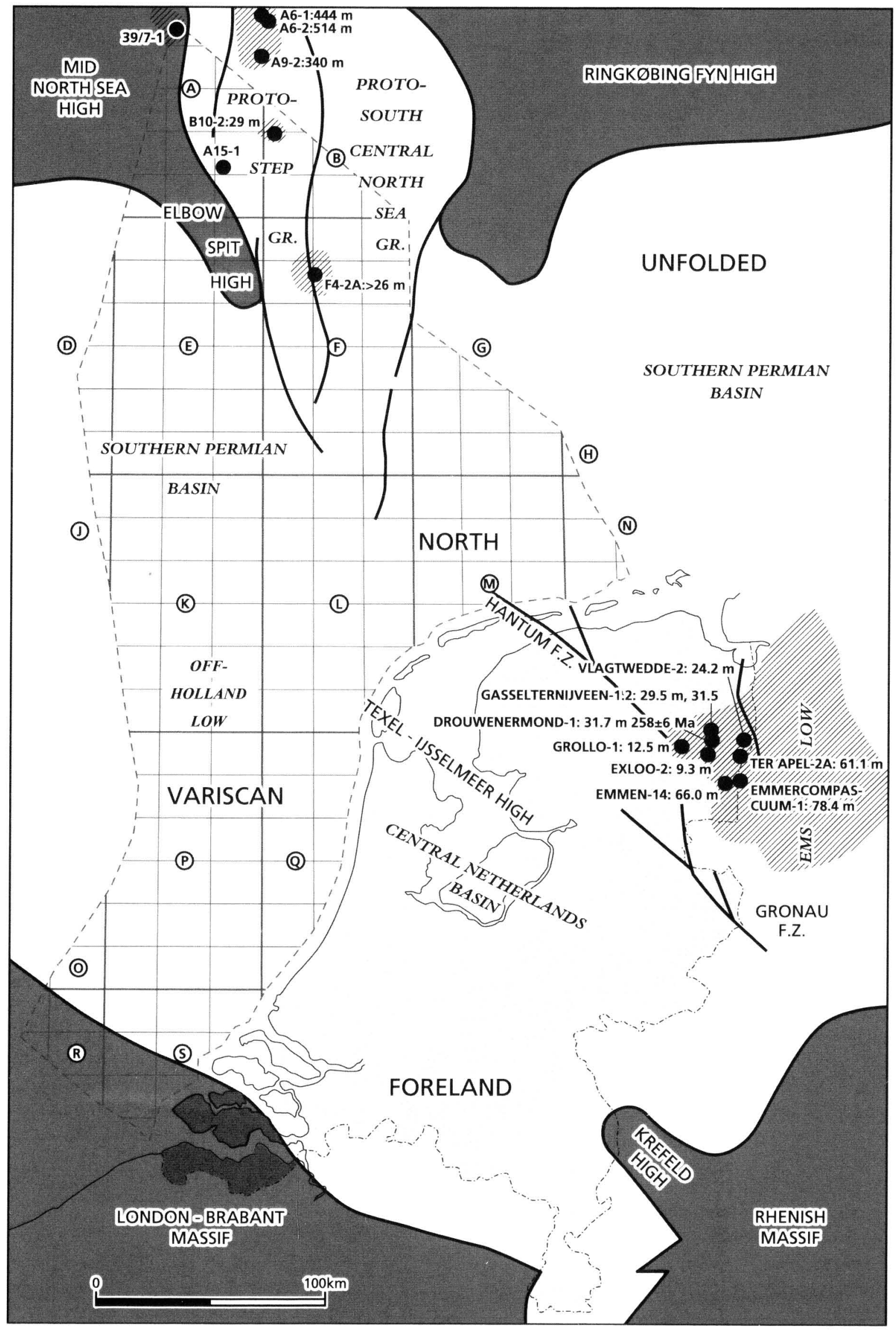

Fig. 6 Areal distribution of Early Permian igneous rock, in conjunction with late Variscan-Saalian structural elements. 
is unconformably overlain by the Zurich Formation. The mudstones of this rock unit include a detrital and tuffaceous deposit, the Wadden Volcaniclastic Member, which has been assigned an approximate Portlandian-early Ryazanian age (Herngreen et al., 1991). The sequence postdates the KimmeridgianVolgian or Oxfordian-Kimmeridgian Zuidwal Volcanic Formation (Fig. 3). Consequently, its stratigraphic age seems to be latest Jurassic (Volgian) or, following Gradstein \& Ogg (1996), earliest Cretaceous (Ryazanian). Supposedly time-equivalent and petrographically comparable volcaniclastic rock has been encountered in well F16-2 (pers. comm. H. Mijnlieff, NITG; no further information available), which is situated in the southern part of the South Central North Sea Graben at the location of a discrete magnetic anomaly (Figs 9 \& 10).

Tuffaceous strata are known from the upper Nieuwerkerk and upper Breeveertien sequences in respectively the West Netherlands Basin and the Broad Fourteens Basin (Figs $1 \&$ 7). Their age is (presumably) Valanginian, thus corresponding in age with some of the intrusions in the subjacent Altena Group. Their pyroclastic source of origin is unknown. The nearest but still distant site with coeval explosive volcanism seems to be the (per)alkaline Wolf RockEpson Shoal igneous centre (K/Ar ages 132, $130 \pm 6$ and $127 \pm 8 \mathrm{Ma}$ ) in the S.W. Approaches, offshore the Cornwall mainland (Harrison et al., 1977, 1979). The centre bears a relation to the early opening of the North Atlantic.

From several younger Cretaceous stratigraphic intervals in Gt. Britain and western Germany tuff horizons have been reported, thus suggesting that tuffaceous fall-out material from distant sources has also been deposited in the Netherlands (cf. Pacey, 1984; Valeton, 1960).

In the offshore well F3-7 (at 2928 m; Figs 1 \& 7) a $1 \mathrm{~cm}$ thick volcanogenic bed occurs in the Callovian Lower Graben Formation, yielding material with a radiometric age of $236 \pm 6 \mathrm{Ma}$ (Appendix). In this case, we are dealing with non-contemporaneous rock (reworked and weathered Rotliegend volcanics?) deposited in the oldest syn-rift formation of the Dutch Central North Sea Graben.

\section{Lower Tertiary}

The Basal Dongen Tuffite Member of the Eocene Dongen Formation (and its equivalents abroad) is distributed throughout and far beyond the northern and central Netherlands into Germany and Gt. Britain (Jacqué \& Thouvenin, 1975; Fig. 9). In the Netherlands the tuffaceous constituents are in gener- al completely (or virtually so) argillised. Its deposition is coeval with pulsed explosive volcanism associated with the initiation of ocean-floor spreading during the earliest Eocene in the region of the Rockall Trough and the Faeroe-Shetland Basin (c. $55 \mathrm{Ma}$; Ritchie et al., 1999), and, assumedly, with volcanism in the present-day Skaggerak area (Ziegler, 1990). The peaked volcanotectonics along the rift northwest of Britain coincided with the opening of the northern North Atlantic.

The age of the Dongen tuffite corresponds with that of a partial overprint event recorded in the intrusion of the Detfurth Formation in well Q7-2 (Dixon et al., 1981). Volcanogenic sediment may also occur the Early Oligocene Boom Clay, since substantial amounts of volcaniclastic material has been supplied to this formation in northern Belgium by the Hocheifel volcanic centre of the Rhenish Massif (Zimmerle, 1993). Similarly, trachytic tephra was shed during the Early Miocene from the Siebengebirge volcanic centre into the adjacent Lower Rhine Embayment (Grünhagen, 1981).

\section{Periods and centres of igneous activity}

The radiometric age determinations and stratigraphic constraints of the igneous rocks and volcanogenic sediments show that temporally restricted magmatic events occurred during the Palaeozoic, Mesozoic and Early Cenozoic. Three significant groups of ages can be distinguished, viz. a mid-Carboniferous to Permian one, a Late(st) Triassic one and a Late Jurassic to early Early Cretaceous one (Figs $1 \& 3$ ). The (near)absence of magmatic activity during the Late Permian and the Early to Middle Triassic is well known from northwestern Europe. This general 'amagmatic' period of thermal relaxation and subsidence corresponds to the intracratonic tectonic stage in between the active Variscan geosynclinal stage and the episodic Mid- to Late Kimmerian taphrogenic stage (Ziegler, 1990).

The geographic distribution of the igneous rocks in the Carboniferous shows two main clusters: one in the northern offshore region and one in the north(eastern) onshore of the Netherlands (Fig. 4). Apparently, the igneous rocks of Carboniferous to Early Permian age are particularly related to (trans)tensional tectonics and thermal mantle-lithosphere thinning associated with the formation of the post-Variscan basin in which the Upper Rotliegend deposits accumulated. The igneous rock in the post-Carboniferous formations show a distribution that is correlatable to a large extent with the main structural features of the Dutch portion of the Central North Sea Graben system (Fig. 5). Altogether, the ascent of the different igneous 


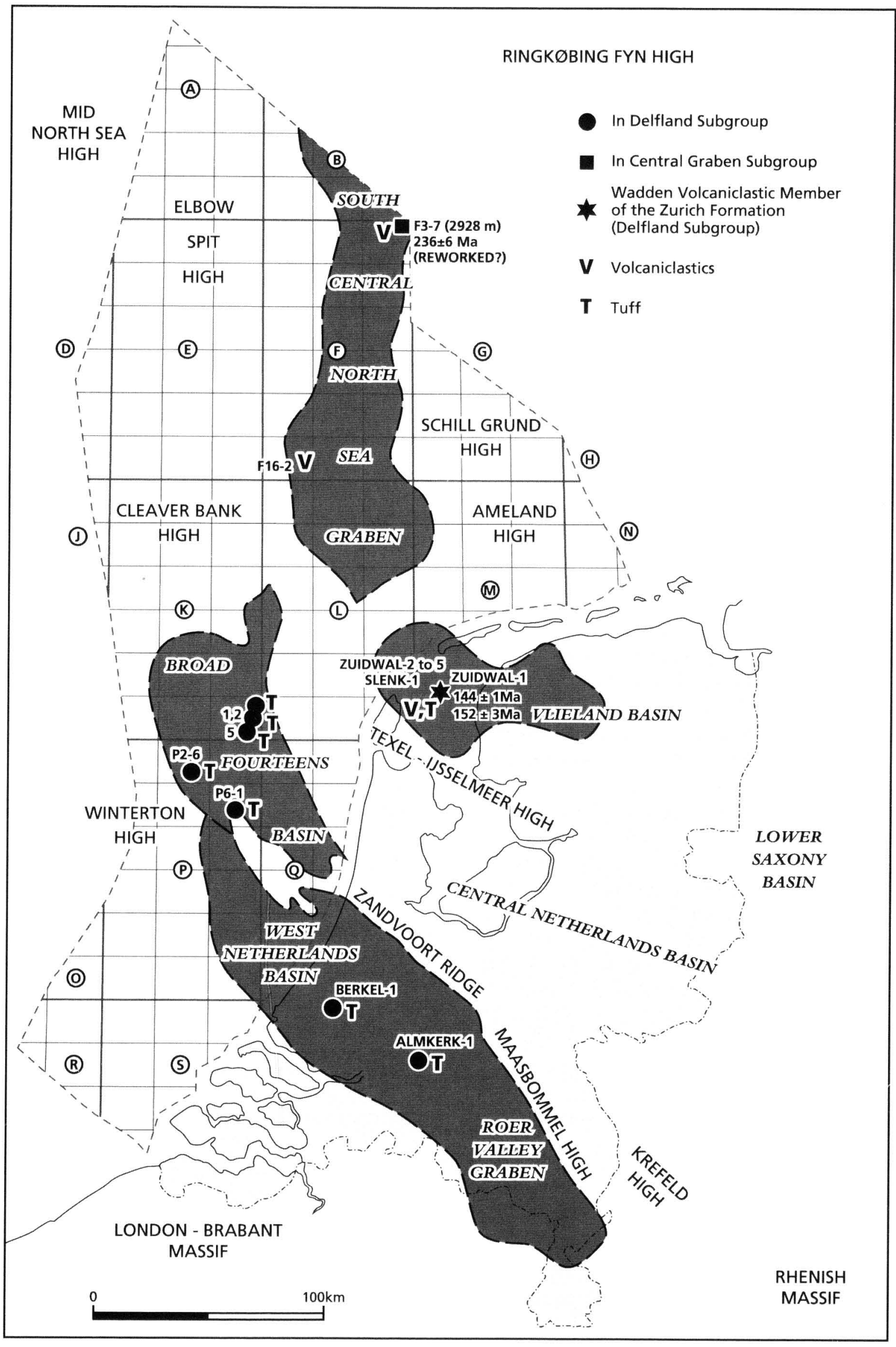

Fig. 7 Areal distribution of Late Jurassic-Early Cretaceous volcanogenic sediment, in conjunction with late Kimmerian structural elements. 
rocks (magmas) is of course a manifestation of heating and melting processes at depth, which, depending on their areal distribution and duration, changed (more or less drastically) the heat flux pattern and subsurface temperature structure. The spacio-temporal distribution of past (tectono)magmatic activity is consequently of importance for source rock maturity analysis.

The following periods of tectonomagmatic activity are recognized (Figs $8 \&$ 9; see also Figs 1 to 3 ):

- 'Early Variscan' (Late Devonian)

- 'Middle Variscan' (mid-Carboniferous)

- 'Late Variscan' (Early Permian)

- Early Kimmerian (late Late Triassic)

- Mid-Kimmerian (mid- to Late Jurassic)

- Late Kimmerian (Valanginian/Hauterivian)

- Austrian (late Albian/Cenomanian)

- Thulean (Early Eocene)

The Carboniferous includes a 'Middle Variscan' pulse of extrusive and intrusive magmatism that corresponds to the Sudetian tectonic phase of short-term uplift and erosion near the Visean-Namurian transition. Successively, an early 'Late Variscan' (early Early Permian) pulse and a later 'Late Variscan' (late Early Permian) pulse of igneous activity can be distinguished for the Saalian orogenic phase (Figs 1 and 3). The Kimmerian isotopic ages from the wells E6-1

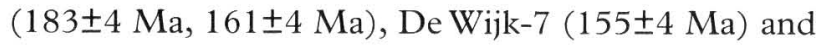

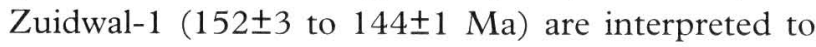
represent successive tectonomagmatic steps, which are, at least with respect to the wells E6-1 and Zuidwal-1, correlative in age with the Mid- to Late Kimmerian development of the 'Upper Jurassic' graben system.

The following centres of dated igneous activity are distinguished in the Netherlands and adjacent German region (Figs 8 \& 10):

I. Elbow Spit Igneous Centre: In this centre volcanism occurred in 'Early Variscan' and 'Late Variscan' time. Intrusive magmatism took place during the MidKimmerian tectonic phase. To the south of the centre some localized 'Late Variscan' and Austrian intrusions are found.

II. Broad Fourteens Igneous Centre: This centre is typified by Austrian intrusions of nephelinites (cf. Dixon et al., 1981). 'Thulean magmatism' has been identified in well L13-3.

III. West Netherlands Igneous Centre: Late Kimmerian nephelinite and basanite intrusions characterize this centre. The alkaline rocks are comparable in magmatic character and time of eruption to those of the Wolf Rock nosean phonolite dated around $130 \mathrm{Ma}$ (cf. Dixon et al., 1981).

IV. Zuidwal Igneous Centre: This centre is represented by a late Mid-Kimmerian volcanic plug (Cottençon et al., 1975; Herngreen et al., 1991) comprising altered phonolites, leucite-bearing lavas and trachytes (Harrison et al., 1979; Perrot \& van der Poel, 1987). Dixon et al. (1981) mention a minor overprint event between about 90 and $120 \mathrm{Ma}$ in the dated sample. Van den Bosch (1983) reports evidence of Late Berriasian magmatism in the nearby region to the east of the onshore Harlingen gas field. A possibly tectonomagmatically-related centre of extrusion may occur in the South Central North Sea Graben at well F16-2.

V. East Groningen Igneous Centre: Igneous rocks of this centre have not yet been reached in wells. They probably intruded during the Late Kimmerian phase. However, an Early Permian age for the intrusion cannot be ruled out (Kettel, 1983)

VI. East Netherlands Igneous Centre: In this centre 'Late Variscan' intrusions and extrusions are most commonly found. In addition, some 'Middle Variscan' (Tesch, 1925, 1928; Tomkeieff, 1944; Tesch \& van Voorthuysen, 1944) and Mid-Kimmerian intrusive activity occurred.

VII. Nagele Igneous Centre: This centre includes the assumedly fault-related 'Middle Variscan' volcanic vent identified by well Nagele-1 at the eastern extension of the Texel-IJsselmeer High. Most likely, the Westphalian of the well includes an early 'Late Variscan' intrusion.

In addition, the following important centres of preTertiary igneous activity occur in Germany close to the Netherlands (Fig. 10):

VIII. Erkelenz Igneous Centre: Most likely, this is a centre of 'Late Variscan' age (see Teichmüller \& Teichmüller, 1971; Bredewout, 1997).

IX. Ems Low Igneous Centre: The East Netherlands Igneous Centre (VI) is essentially the westward extension of this major graben-like centre of late 'Late Variscan' magmatism and syn-tectonic deposition of volcaniclastic strata (see Eckhart, 1971, 1979; Eigenfeld \& Eigenfeld-Mende, 1986; Marx et al., 1995).

X. Bramsche Massif Igneous Centre: This large centre of 


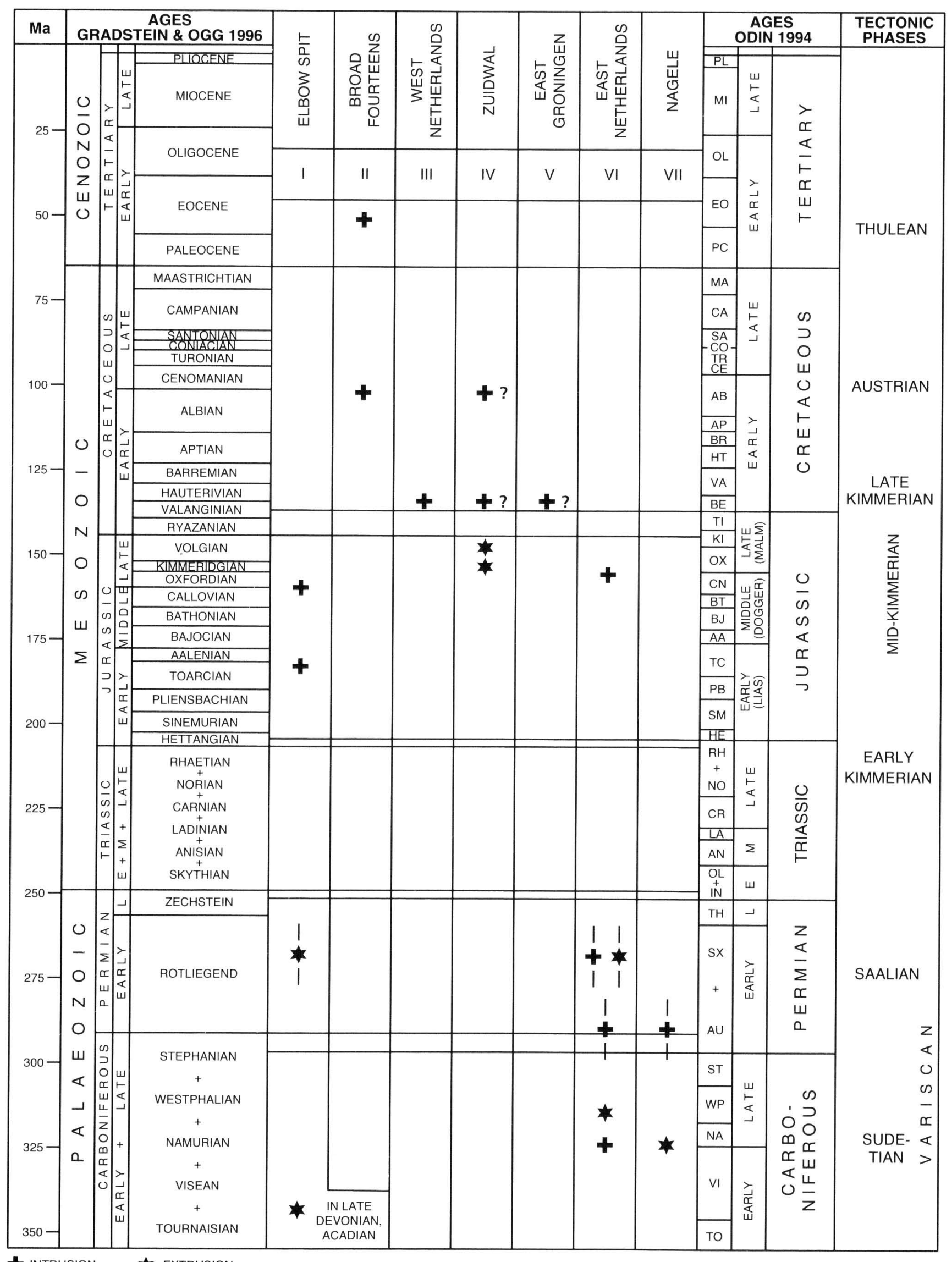

INTRUSION

EXTRUSION

Fig. 8 Temporal distribution of centres of igneous activity in the Netherlands, in conjunction with the identified tectonic phases. 


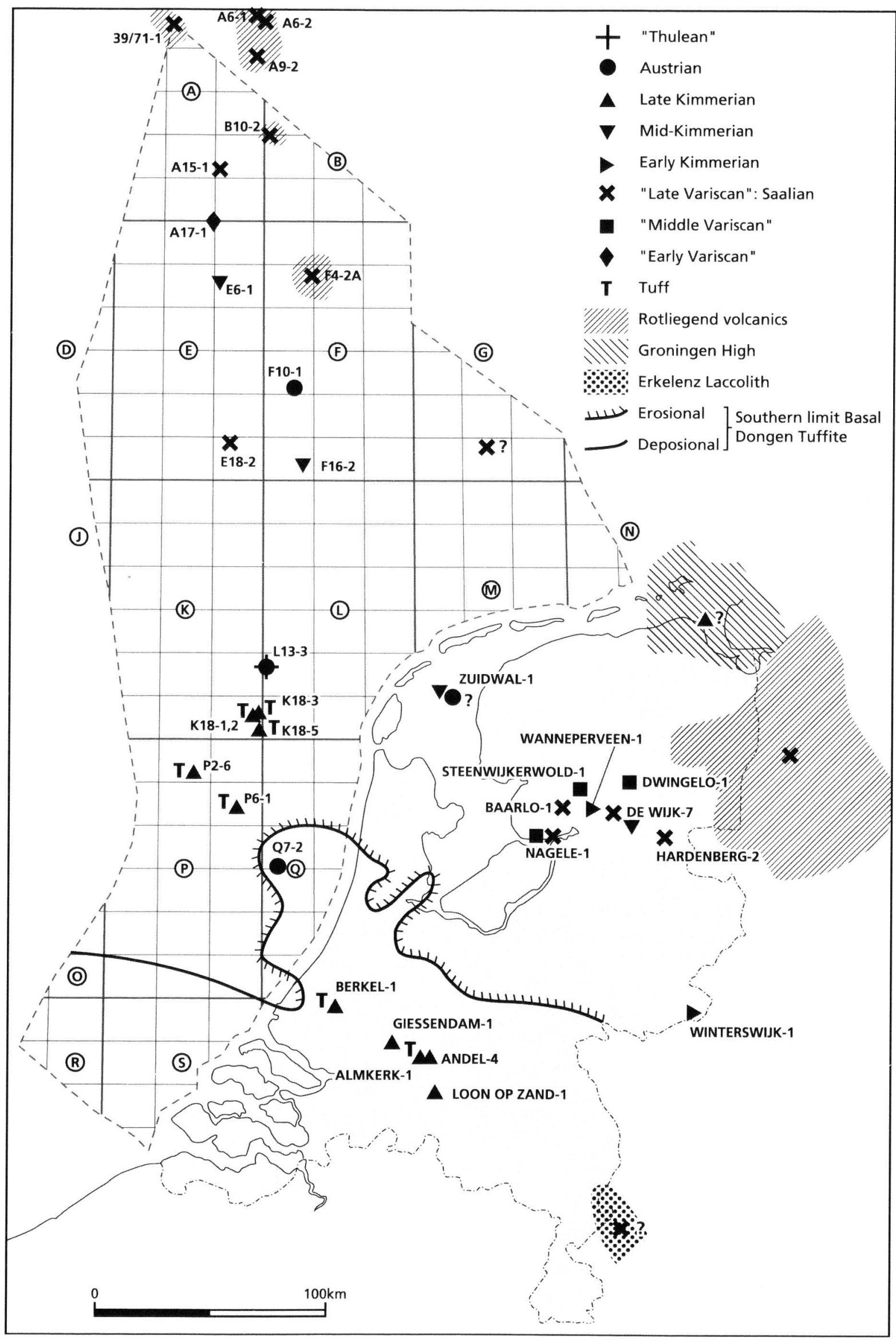

Fig. 9 Areal distribution of igneous activity in the Netherlands. 


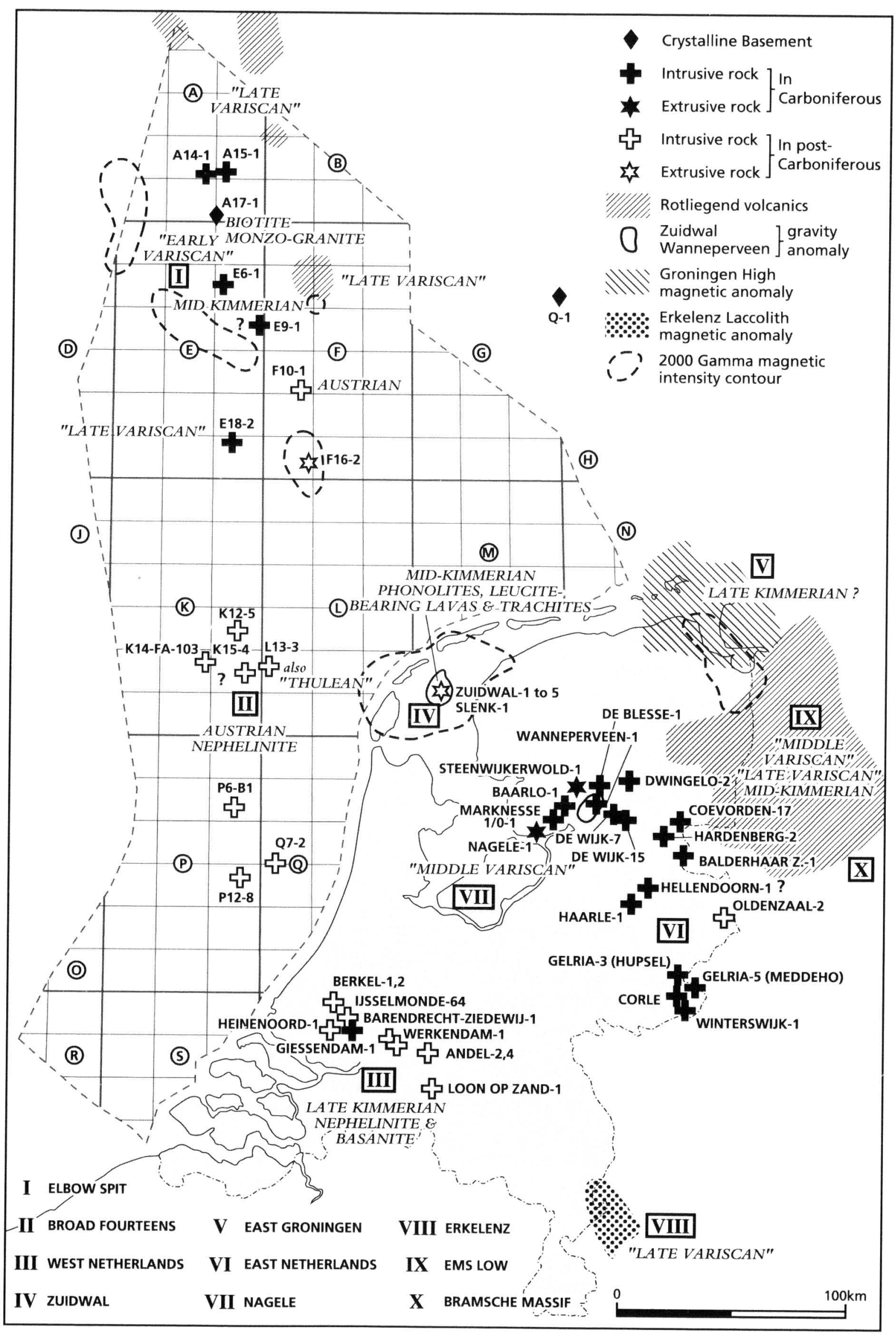

Fig. 10 Centres of Palaeozoic and Mesozoic igneous activity in the Netherlands. 
intrusion in the Lower Saxony tectogene is Cretaceous in age (see Stadler \& Teichmüller, 1971; Buntebarth \& Teichmüller, 1979).

\section{Tectonomagmatic outline history}

The correlation of episodes of igneous activity with phases of orogenic deformation (Fig. 8) indicates that geographically widespread but time-restricted geological processes controlled the geological development of the Netherlands to a significant extent. In fact, the successive stages of tectonomagmatic evolution reflect major plate-tectonic events in Western Europe. Generally, these events created an evolving, largescale framework which controlled the depositional history.

Largely situated to the south of the Netherlands in northern France and Belgium, the anticlinal LondonBrabant Massif represents an extensive, WNW-ESE trending structural high that comprises a PreCambrian crystalline basement and metasedimentary and volcanic rocks of Early Palaeozoic age (André, 1991). In view of the great thicknesses of the Early Palaeozoic sedimentary series without significant molasse-type deposits, the absence of intensive metamorphism and the subordinate presence of Late Ordovician-Middle Silurian calc-alkaline magmatism (confined to an arcuate belt along the southern margin of the massif), Caledonian subsidence and uplift of the Pre-Cambrian basement blocks has been inferred rather than the formation of an autonomous orogenic belt (Walter, 1980; Ziegler, 1990). At the same time, Laurussia originated by the collision of Baltica/Fennoscandinavia and Laurentia/Greenland (after closing the Iapetus Ocean).Concurrently, the London-Brabant Massif experienced a plate-tectonic reorganization that included an accretionary docking of a northwards moving 'Brabantia' microplate of Precambrian basement (composed of Belgium and southern England) against the newly formed Laurussian megacontinent (André, 1991). The Early Palaeozoic magmatism of the London-Brabant Massif coincided probably with plate subduction related to the closure of a mid-European basin that separated Baltica from Armorica (André et al., 1986).

From mid-Palaeozoic (Devonian) time onwards, the massif behaved as a relatively stable, 'Early Variscan' shelfal platform (with the exception of a main period of uplift in the Jurassic; see below) that was originally part of Gondwana (Walter, 1980; Bless et al., 1983). A WNW-ESE trending shear zone developed along the late Ordovician-Middle Silurian magmatic belt in the Middle Devonian (c. $375 \mathrm{Ma}$; Late Givetian; André \& Deutsch, 1985).
During the Late Carboniferous, partial overthrusting and uplifting occurred south of the rapidly subsiding Variscan foreland basin and a more stable Variscan foreland zone closer to the crest of the London-Brabant Massif. This tectonism occurred in concomitance with the development of the 'Middle to early Late Variscan' tectonic collage in response to the climactic collision of the northward-drifting Gondwana with the slower moving Laurussia that formed the Pangaea supercontinent. In the process, characteristic NW-SE striking faults developed in response to compressional tectonic stress, delimiting by differential fault motion the Texel-IJsselmeer and Zandvoort-Maasbommel Krefeld systems of highs in the vicinity of the Variscan foredeep along the southern margin of the huge Mid European Basin. The latter depocentre extended nearly over the entire Netherlands during the Carboniferous. It occurred between the London-Brabant Massif and the northern Caledonian uplands from which the Mid North Sea-Ringkøbing Fyn system of highs developed between the Northern and Southern Permian basins in Late Carboniferous-Early Permian time (Fig. 4; Ziegler, 1990).

In the northern part of the Dutch realm Caledonian crystalline basement has twice been reached by the bit (Fig. 4). 'Early Variscan' volcanism occurred here during the Late Devonian in the Elbow Spit region (Figs 2, 8 and 9). Within the 'Middle to Late Variscan' foredeep magmatism was confined to the Nagele and East Netherlands igneous centres (Figs 8 to 10). Final Variscan (sub-)volcanics developed in the Elbow Spit and East Netherlands igneous centres (Figs 8 to 10). Ascent of Carboniferous and Permian magma in these centres occurred along deep-seated crustal fault zones (Fig. 4) and under the inducive influence of tectonic instability that was enhanced in concomitance with the pre-Saalian Variscan orogenic pulses (Fig. 8). This punctuated tectonism may have created localized (trans)tensional stress habitats which allowed magma to rise through the associated wrench tectonics. The Sudetian phase of magmatism was apparently coincident with the initial development of the Proto-South Central North Sea Graben and the plate-tectonic closure of the Rhenohercynian back-arc basin (Ziegler, 1990). The 'Late Variscan' orogenic phase affected the area in particular, causing faulting and differential uplift and truncation of the Carboniferous series.

During the subsequent break-up of Pangaea, the Gondwana-derived London-Brabant terrane remained a stable block, whilst Permo-Carboniferous to Triassic rifting was initiated to the north of the massif in response to E-W trending tensional stress related to 
the formation of the Southern Permian Basin and the opening of the Atlantic Ocean (Glennie, 1986, 1995; Ziegler, 1990). The resultant extensional block movements created a N-S trending volcanotectonic Ems Low along the eastern border of the Netherlands (Marx et al., 1995). In the northern offshore a similarly oriented Proto-South Central North Sea Graben and Proto-Step Graben developed (Fig. 4). In and around these volcanotectonic structures alkaline rather than calc-alkaline Rotliegend volcanics accumulated (Figs $5 \& 6$; pers. comm. R.P. Kuijper). The volcanics extruded apparently during two main episodes, an early 'Late Variscan' (c. 295-285 Ma) one that straddled the Carboniferous-Permian boundary and a late 'Late Variscan' (c. 275-260 Ma) one during the late Early Permian (Fig. 8). Each of these seems to reflect a phase of kinematic re-organization (foreland rift/wrench tectonics). The first followed upon the Asturian termination of crustal shortening at the end of the Westphalian (van Wees et al., 2000), an event that is stratigraphically marked by an unconformity (Fig. 2). The second directly preceded the imminent post-Saalian collapse of the Variscan fold belt during the thermal cooling of the adjoining foreland lithosphere (Ziegler, 1990) that caused the TexelIJsselmeer High to subside.

In the region of the igneous centres of Eastern Netherlands and of the Ems Low rapid depositional thickness variations along the Early Permian troughs indicate depositional control by syn-sedimentary activity along faults. The faults may have been avenues for the ascent of intrusive and extrusive basic melts, which were sourced from the hot mantle and assimilated material from the heated crust on their way upwards (Eckhardt, 1979). Greatest thicknesses of volcanics and volcaniclastics have been found in the Ems Low. Partially following the structural framework of the Variscan foredeep basins, the Southern Permian Basin came into existence when Variscan crustal shortening had ceased in the Westphalian. A complex wrench-fault system was established by a transtensional, intracontinental stress regime induced by westward movements of Gondwana relative to Laurussia (Arthaud \& Matte, 1977; Ziegler, 1990).

After the polyphase episode of Permo-Carboniferous magmatism, concomitant re-activation of deep crustal fractures and regional uplift and erosion, thermal contraction and subsidence of the late Early Permian lithosphere resulted in the Southern Permian Basin. In this large and land-locked basin Upper Rotliegend clastics and Zechstein evaporites accumulated with great maximum thicknesses under relatively quiet tectonic conditions (van Wees et al.,
2000). Overall, this regime of tectonic subsidence persisted into the Triassic.

Tectonism peaked briefly with the Pfalzian and Hardegsen phases at the beginning of the Triassic (Fig. 3). These phases resulted in the closure of the Southern Permian Basin and in the formation of the erosional Central Netherlands Swell (Fig. 1) at the approximate location of the pre-existing TexelIJsselmeer High.

After a long period of rest, magmatism resumed during the latest Triassic, possibly in association with the Early Kimmerian orogenic pulse (Figs 3 \& 9) that may correlate to a change in motion of Greenland and Rockall with respect to Eurasia (Knott et al., 1993). After this tectonic event, an extended period of cooling and uplift of the London-Brabant Massif (apatite fission track ages between $209 \mathrm{Ma}$ and $146 \mathrm{Ma}$; Vercoutere \& van den Haute, 1993) occurred up to about the volcanic climax during the later part of the Kimmerian phase (between c. $152 \mathrm{Ma}$ and c. 144 $\mathrm{Ma})$ in the Vlieland Basin. During this period of relative magmatic quiescence, a Mid-Kimmerian intrusion occurred in the Elbow Spit centre (c. $183 \mathrm{Ma}$ Figs 8 to 10 ) that might be related to the impingement of a broad-based, transient plume head at the base of the lithosphere, inducing an initial, ToarcianAalenian uplift of the Central North Sea Dome (Underhill \& Partington, 1993). The joint duration of the later Kimmerian tectonic phases (Figs 3, 7 to 9) encompasses main reorganizations for the motion of Africa relative to Europe during the Bathonian, midCallovian, early Kimmeridgian and late Berriasian. Each of these reorganizations is linked to a major rift event in the peri-Atlantic region. Those of the midCallovian and late Berriasian are also corresponding to relative motion between Greenland and Rockall (Knott et al., 1993). Excepting the first-mentioned episode, they seem to be correlative to short-term magmatism in the Dutch realm (Fig. 3). They preceded the plate kinematics leading to the opening of the North Atlantic. The mid-Callovian magmatic event in the Elbow Spit igneous centre (c. $161 \mathrm{Ma}$ ) marks the N-S propagation of the adjoining Central North Sea Graben into the Netherlands offshore (structurally guided by the Proto-South Central North Sea Graben). The polyphase Kimmerian taphrogenic period was most notably accompanied by the Kimmeridgian/Volgian formation of the alkaline Zuidwal Volcano (c. $152 \mathrm{Ma}$ to c. $144 \mathrm{Ma}$; Figs 3 \& 10) in the pull-apart Vlieland Basin, as well as by the subsequent collapse of its magma chamber and partial destruction of its structure during the Ryazanian (Perrot \& van der Poel, 1987). The local volcanicity has been explained by assuming a magmatically- 


\begin{tabular}{|c|c|c|c|c|c|c|c|c|c|c|c|}
\hline WELL & \begin{tabular}{|c|} 
DATED \\
IGNEOUS INTERVAL \\
$\mathrm{m}$
\end{tabular} & $\begin{array}{l}\text { UNDERLYING } \\
\text { ROCK-UNIT }\end{array}$ & $\begin{array}{l}\text { OVERLYING } \\
\text { ROCK-UNIT }\end{array}$ & $\begin{array}{l}\text { DATED } \\
\text { TYPE }\end{array}$ & $\begin{array}{l}\text { SAMPLE } \\
\text { DEPTH } \\
\mathrm{m}\end{array}$ & $\begin{array}{l}\text { RADIOMETRIC } \\
\text { METHOD }\end{array}$ & $\begin{array}{c}\mathbf{K} \\
\% \mathbf{W t}\end{array}$ & $\begin{array}{c}\text { RADIOGENIC } \\
40 \mathrm{Ar} \\
\mathrm{ppb}\end{array}$ & $\begin{array}{c}\text { ATMOSPHERIC } \\
40 \mathrm{Ar} \\
\% \text { TOTAL } 40 \mathrm{Ar}\end{array}$ & $\begin{array}{c}\text { RADIOMETRIC } \\
\text { AGE } \\
\mathrm{Ma}\end{array}$ & $\begin{array}{l}\text { REFERENCES } \\
\text { REMARKS }\end{array}$ \\
\hline A17-1 & $\begin{array}{c}2157.0-2195.0 \\
3013,0-3043,7 \text { T T.D. }\end{array}$ & L. BUCHAN & $\begin{array}{l}\text { U. BUCHAN } \\
\text { PATCH }\end{array}$ & \begin{tabular}{|c|}
$?$ \\
CORE \\
\end{tabular} & $\begin{array}{c}? \\
\sim 3043 \\
\end{array}$ & Ar/Ar & & & & $\begin{array}{c}341 \pm 30 \\
\text { MIN. } 346 \pm 7\end{array}$ & $\begin{array}{c}\text { MOBIL } \\
\text { FROST ET AL, } 1981\end{array}$ \\
\hline \multirow[t]{2}{*}{ E6-1 } & \multirow[t]{2}{*}{$2405.0-2423.0$} & \multirow[t]{2}{*}{$\begin{array}{c}\text { FARNE } \\
\text { ELLEBOOG }\end{array}$} & \multirow[t]{2}{*}{$\begin{array}{c}\text { FARNE } \\
\text { ELLEBOOG }\end{array}$} & SWS & 2415.0 & K/Ar & $\begin{array}{l}0.891 \\
0.885\end{array}$ & $\begin{array}{l}10.47 \\
10.52 \\
9.995 \\
\end{array}$ & $\begin{array}{l}23 \\
21 \\
37 \\
\end{array}$ & $161 \pm 4$ & \\
\hline & & & & SWS & 2420.0 & $\mathrm{~K} / \mathrm{Ar}$ & $\begin{array}{l}1.158 \\
1.153 \\
\end{array}$ & $\begin{array}{l}15.63 \\
15.24\end{array}$ & $\begin{array}{l}24 \\
29 \\
\end{array}$ & $183 \pm 4$ & \\
\hline E18-2 & $4437.0-4452.0$ & $\begin{array}{c}\text { LIMBURG } \\
\text { KLAVERBANK }\end{array}$ & $\begin{array}{c}\text { LIMBURG } \\
\text { KLAVERBANK }\end{array}$ & swS & 4439.0 & $\mathrm{~K} / \mathrm{Ar}$ & $\begin{array}{l}0.143 \\
0.142 \\
\end{array}$ & $\begin{array}{l}2.87 \\
2.97\end{array}$ & $\begin{array}{l}59 \\
49 \\
\end{array}$ & $274 \pm 7$ & \\
\hline F3-7 & $2928.0-2928.1$ & $\begin{array}{l}\text { CENTRAL GRABEN } \\
\text { LOWER GRABEN } \\
\end{array}$ & $\begin{array}{l}\text { CENTRAL GRABEN } \\
\text { LOWER GRABEN }\end{array}$ & CORE & $\sim 2928.05$ & $\mathrm{~K} / \mathrm{Ar}$ & $\begin{array}{l}2.80 \\
2.84\end{array}$ & $\begin{array}{l}48.98 \\
49.22\end{array}$ & $\begin{array}{l}5 \\
6 \\
\end{array}$ & $236 \pm 6$ & VOLCANICLASTICS \\
\hline F10-1 & $3426,0-3460,0$ T.D. & & ZECHSTEIN SALT & CORE & 3450.25 & $\mathrm{~K} / \mathrm{Ar}$ & $\begin{array}{l}3.77 \\
3.77\end{array}$ & $\begin{array}{l}25.40 \\
28.50 \\
25.87 \\
27.08\end{array}$ & $\begin{array}{l}28 \\
30 \\
29 \\
30 \\
\end{array}$ & $99 \pm 5$ & \\
\hline L13-3 & $\sim 1820$ & ZECHSTEIN SALT & ZECHSTEIN SALT & CTGS & $\sim 1820$ & $\mathrm{Ar} / \mathrm{Ar}$ & & & & $\begin{array}{c}101 \pm 1 \\
\text { OVERPRINT AT } \\
51.9 \pm 0.3\end{array}$ & $\begin{array}{c}\text { FROST, 1978; } \\
\text { DIXON ET AL., } 1981 \\
\end{array}$ \\
\hline Q7-2 & $\sim 3450$ (?) & $\begin{array}{l}\text { M. BUNTSANDST } \\
\text { DETFURTH }\end{array}$ & $\begin{array}{l}\text { M. BUNTSANDST } \\
\text { DETFURTH }\end{array}$ & CTGS & $\sim 3450(?)$ & $\mathrm{Ar} / \mathrm{Ar}$ & & & & $\begin{array}{c}100 \pm 4 \\
(95 \pm 2 \text { TO } 106 \pm 2) \\
\end{array}$ & DIXON ET AL., 1981 \\
\hline ANDEL-4 & $\begin{array}{c}1651.4-1652.1 \mathrm{OA} \\
1657.1-1658.0 \\
\end{array}$ & $\begin{array}{c}\text { ALTENA } \\
\text { U. WERKENDAM }\end{array}$ & $\begin{array}{c}\text { ALTENA } \\
\text { U. WERKENDAM }\end{array}$ & (CORE) & $?$ & $\mathrm{Ar} / \mathrm{Ar}$ & & & & $133 \pm 2$ & DIXON ET AL., 1981 \\
\hline BAARLO-1 & $1772.5-1775.0$ & $\begin{array}{l}\text { LIMBURG } \\
\text { MAURITS } \\
\text { (WP) }\end{array}$ & $\begin{array}{l}\text { U. ROTLIEGEND } \\
\text { SLOCHEREN }\end{array}$ & CORE & 1775.6 & $\mathrm{~K} / \mathrm{Ar}$ & $\begin{array}{l}0.939 \\
0.959\end{array}$ & $\begin{array}{l}19.27 \\
16.93 \\
20.11 \\
19.22 \\
\end{array}$ & $\begin{array}{l}28 \\
24 \\
25 \\
40\end{array}$ & $266 \pm 18$ & \\
\hline BERKEL-1 & $\sim 2944-2970$ & \begin{tabular}{|c|} 
ALTENA \\
POSIDONIA SHALE \\
\end{tabular} & $\begin{array}{c}\text { ALTENA } \\
\text { L. WERKENDAM } \\
\end{array}$ & CTGS & $\mid \sim 2964-66$ & $\mathrm{~K} / \mathrm{Ar}$ & $\begin{array}{l}1.23 \\
1.25\end{array}$ & $\begin{array}{l}19.30 \\
21.77 \\
17.54 \\
\end{array}$ & $\begin{array}{l}29 \\
13 \\
49 \\
\end{array}$ & $214 \pm 25$ & $\begin{array}{c}\text { AGE } \\
\text { INCONNECT } \\
\end{array}$ \\
\hline $\begin{array}{c}\text { DROUWENER- } \\
\text { MOND-1 }\end{array}$ & $3920.5-3953.5$ & $\begin{array}{l}\text { LIMBURG } \\
\text { DE LUTTE }\end{array}$ & $\begin{array}{c}\text { ZECHSTEIN } \\
\text { COPPER SHALE }\end{array}$ & "CORE" & 3921.0 & $\mathrm{~K} / \mathrm{Ar}$ & $\begin{array}{l}2.07 \\
2.08\end{array}$ & $\begin{array}{l}39.89 \\
39.96\end{array}$ & $\begin{array}{l}3 \\
4\end{array}$ & $258 \pm 6$ & VOLCANICLASTICS \\
\hline DWINGELO-2 & $3754.3-3792.2$ T.D. & & $\begin{array}{l}\text { LIMBURG } \\
\text { CAUMER } \\
\text { (WP A?) }\end{array}$ & CORE & 3788.8 & $\mathrm{~K} / \mathrm{Ar}$ & \begin{tabular}{l|}
0.218 \\
0.221 \\
0.217 \\
\end{tabular} & $\begin{array}{l}5.48 \\
5.38 \\
5.17 \\
\end{array}$ & $\begin{array}{l}7 \\
75 \\
76 \\
86\end{array}$ & $322 \pm 15$ & \\
\hline $\begin{array}{l}\text { GIESSEN- } \\
\text { DAM-1 }\end{array}$ & $1190.0-1218.0$ & $\begin{array}{l}\text { NIEUWERKERK } \\
\text { SCHIELAND } \\
\text { ALBLASSERDAM }\end{array}$ & $\begin{array}{l}\text { NIEUWERKERK } \\
\text { SCHIELAND } \\
\text { ALBLASSERDAM }\end{array}$ & CTGS & $\sim 1220$ & $\mathrm{~K} / \mathrm{Ar}$ & $\begin{array}{l}1.56 \\
1.59\end{array}$ & $\begin{array}{l}13.19 \\
17.82 \\
12.78 \\
12.84 \\
\end{array}$ & $\begin{array}{l}18 \\
14 \\
58 \\
51\end{array}$ & $125 \pm 25$ & \\
\hline $\begin{array}{l}\text { HARDEN- } \\
\text { BERG-2 }\end{array}$ & $3376.5-3441.0$ & $\begin{array}{l}\text { LIMBURG } \\
\text { RUURLO } \\
\text { (WP B) }\end{array}$ & $\begin{array}{l}\text { LIMBURG } \\
\text { RUURLO } \\
\text { (WP B) }\end{array}$ & CORE & 3410.6 & K/Ar & $\begin{array}{l}1.93 \\
1.92 \\
1.94 \\
\end{array}$ & $\begin{array}{l}4.24 \\
4.19\end{array}$ & $\begin{array}{l}82 \\
86\end{array}$ & $290 \pm 16$ & \\
\hline $\begin{array}{l}\text { LOON OP } \\
\text { ZAND-1 }\end{array}$ & $2572.0-2610.0$ (PROB.) & $\begin{array}{c}\text { ALTENA } \\
\text { AALBURG }\end{array}$ & $\begin{array}{c}\text { ALTENA } \\
\text { AALBURG }\end{array}$ & (CORE) & $?$ & $\mathrm{Ar} / \mathrm{Ar}$ & & & & $\begin{array}{c}132 \pm 3, \text { COULD } \\
\text { BE BETWEEN } \\
140-150 \\
\end{array}$ & DIXON ET AL., 1981 \\
\hline NAGELE-1 & $2772.5 \cdot 2776.0$ & $\begin{array}{l}\text { LIMBURG } \\
\text { EPEN }\end{array}$ & $\begin{array}{l}\text { LIMBURG } \\
\text { EPEN }\end{array}$ & SWS & 2774.0 & K/Ar & $\begin{array}{l}0.872 \\
0.857\end{array}$ & $\begin{array}{l}21.70 \\
21.20\end{array}$ & $\begin{array}{l}25 \\
23\end{array}$ & $327 \pm 8$ & \\
\hline $\begin{array}{l}\text { STEENWIJKEF- } \\
\text { WOLD-1 }\end{array}$ & $1937.5 \cdot 1944.5$ & $\begin{array}{l}\text { LIMBURG } \\
\text { RUURLO }\end{array}$ & $\begin{array}{l}\text { LIMBURG } \\
\text { RUURLO }\end{array}$ & CORE & 1940.5 & K/Ar & $\begin{array}{l}0.445 \\
0.445 \\
\end{array}$ & $\begin{array}{l}9.63 \\
9.81\end{array}$ & $\begin{array}{l}62 \\
62 \\
\end{array}$ & $291 \pm 8$ & \\
\hline $\begin{array}{l}\text { WANNEPER- } \\
\text { VEEN-1 }\end{array}$ & $2030.5-2035.0$ & $\begin{array}{l}\text { LIMBURG } \\
\text { (WP A) }\end{array}$ & $\begin{array}{l}\text { LIMBURG } \\
\text { (WP A) }\end{array}$ & CORE & 2034.0 & $\mathrm{~K} / \mathrm{Ar}$ & $\begin{array}{l}1.67 \\
1.67\end{array}$ & $\begin{array}{l}2.01 \\
2.37 \\
2.85 \\
\end{array}$ & $\begin{array}{l}42 \\
45 \\
39 \\
\end{array}$ & $217 \pm 20$ & \\
\hline $\begin{array}{l}\text { WINTERS- } \\
\text { WIJK-1 }\end{array}$ & $4089.5-4149.5$ & $\begin{array}{c}\text { EPEN } \\
\text { (NM A/B ?) }\end{array}$ & $\begin{array}{c}\text { EPEN } \\
\text { (NM A/B?) }\end{array}$ & CORE & 4150.0 & $\mathrm{~K} / \mathrm{Ar}$ & $\begin{array}{l}1.43 \\
1.43 \\
\end{array}$ & $\begin{array}{l}23.47 \\
22.59\end{array}$ & $\begin{array}{l}23 \\
15 \\
\end{array}$ & $218 \pm 6$ & \\
\hline DE WIJK-7 & $2443.0 \cdot 2486.0$ & $\begin{array}{l}\text { TUBBERGEN } \\
\text { (WP B/C) }\end{array}$ & $\begin{array}{l}\text { TUBBERGEN } \\
\text { (WP B/C) }\end{array}$ & CORE & 2456.1 & $\mathrm{~K} / \mathrm{Ar}$ & $\begin{array}{l}0.763 \\
0.757 \\
\end{array}$ & $\begin{array}{l}8.56 \\
8.44\end{array}$ & $\begin{array}{l}39 \\
41 \\
\end{array}$ & $155 \pm 4$ & \\
\hline & $2684.0-2691.0$ & $\begin{array}{l}\text { TUBBERGEN } \\
\text { (WP A) }\end{array}$ & $\begin{array}{l}\text { TUBBERGEN } \\
\text { (WP ABB) }\end{array}$ & CORE & 2690.5 & $\mathrm{~K} / \mathrm{Ar}$ & $\begin{array}{l}3.30 \\
3.31 \\
\end{array}$ & $\begin{array}{l}71.74 \\
71.77\end{array}$ & $\begin{array}{l}6 \\
6 \\
\end{array}$ & $289 \pm 7$ & \\
\hline ZUIDWAL-1 & $1944.0-3002.0$ T.D. & - & $\begin{array}{l}\text { RIJNLAND } \\
\text { VLIELAND SST. } \\
\text { FRIESLAND }\end{array}$ & $\begin{array}{l}? \\
? \\
?\end{array}$ & $\begin{array}{l}? \\
?\end{array}$ & $\begin{array}{c}\mathrm{Ar} / \mathrm{Ar} \\
\mathrm{Ar} / \mathrm{Ar}-\mathrm{K} / \mathrm{Ar} \\
\mathrm{K} / \mathrm{Ar}\end{array}$ & & & & $\begin{array}{c}144 \pm 1, \text { OVERPRINT } \\
\text { BETWEEN } 90-120 \\
152 \pm 3,145 \\
\end{array}$ & \begin{tabular}{|c|} 
DIXON ET AL., 1981 \\
PERROT \& V.D. POEL, 1987 \\
HARRISON ET AL., 1979 \\
\end{tabular} \\
\hline
\end{tabular}

Appendix: Isotopic age determinations of igneous rocks encountered in on- and offshore wells drilled in the Netherlands. Note that the quality of the radiometric ages is variable and sometimes difficult to evaluate in the absence of sufficient documentation. The possibility of a significant error should be taken into account, particularly of the $\mathrm{K} / \mathrm{Ar}$ ages obtained on bulk rocks that have suffered some degree of alteration, as is the case in many of these rocks. Stratigraphic ages: NM = Namurian; WP = Westphalian. Sample types: CTGS = cuttings; SWS = sidewall sample.

enriched lithosphere beneath the Texel-IJsselmeer High and an outpour of volcanic melt due to crustal stretching along a roughly NW-SE trending transcurrent fault north of the high (Herngreen et al., 1991). Rifting and wrenching abated and ceased altogether during the early Early Cretaceous in consistency with the terminal stage of the breakup of Pangaea (including the Labrador Rift and the opening of the Gulf of Biscay, c. $130 \mathrm{Ma}$ ).

During later Cretaceous time, a post-orogenic sag basin developed above a cooling lithosphere and in a regional stress field of compressive character that was governed by the collision of Africa and Europe. Correspondingly, North Atlantic spreading seems to be correlative with the general absence of magmatism in the Dutch North Sea region. The Austrian tectonomagmatic pulse (c. 100 Ma; Fig. 8) was contemporaneous with an important phase of early Pyrenean uplift, sediment brecciation, lherzolite emplacement and metamorphism (c. $100 \mathrm{Ma}$ ) in the North Pyrenean Zone. The event has been attributed to extensional-transcurrent motion, crustal thinning and intermittent local compression (Vielzeuf \& Kornprobst, 1984). From the late Late Cretaceous onwards, the basin was subjected to approxinately $\mathrm{N}$ $\mathrm{S}$ directed Alpine compression pulses which caused variably prominent inversion of Late Jurassic-Early Cretaceous basins until the Early Tertiary. The widespread and pronounced regime of compressional tectonics explains the complete absence of (significant) igneous activity since the Early Cretaceous-Late Cretaceous transition (Fig. 8).

\section{Conclusion}

Episodes of Palaeozoic and Mesozoic magmatism in the Netherlands appear to be correlative to widespread orogenic phases which repeatedly modified the 
tectonic setting of the Dutch realm by the emplacement of a new structural grain in concomitance with changing intra-plate stress regimes. These modifications accompanied plate-tectonic reorganizations associated with the formation and subsequent breakup of the large-scale Caledonian, Variscan and Kimmerian plate assemblies. The Palaeozoic Caledonian and Variscan orogenies along plate sutures are reflected by intra-plate igneous activity that was facilitated by distant wrench and rift tectonics induced by the convergence and collision of Gondwana and Laurussia. The Mesozoic break-up of the resultant Pangaea supercontinent co-occured with the development of large-scale rifting. The concomitant extension and thermomechanical attenuation and weakening of the lithosphere lead similarly in the Dutch realm to localized intrusive and extrusive magmatism in co-occurrence with an increasing heat flow and a structural re-organization of the tectonic grain including re-activation of deep crustal faults. In general, pre-existing tectonic features conformed to the prevailing kinematic stress regime. As a result, fault systems responded in the Dutch realm to tectonic forces by creating active strike-slip habitats in which syn-orogenic wrench and rift deformation allowed magma to ascent from the mantle at smallscale, sometimes intermittently re-activated igneous centres at major crustal fracture systems.

\section{Acknowledgements}

The Nederlandse Aardolie Maatschappij B.V. (Assen) is thanked for permission to publish this paper based on a previous company report by the author. The release of additional well data by the Wintershall North Sea B.V. (The Hague) is also gratefully acknowledged. Thanks are also due to Dr. R.P. Kuijper (Economics, Energy \& Natural Resources, Leiden) and Dr. H.E. Rondeel (Amstelveen) for comments on an earlier version of the manuscript. The author is particularly indebted to Dr. Kuijper for placing unpublished data at his disposal and for permission to use it for this publication. This is a contribution of the Vening Meinesz Research School of Geodynamics (VMSG) of the Netherlands Research School of Sedimentary Geology (NSG).

\section{References}

André, L., 1991. The concealed crystalline basement in Belgium and the 'Brabantia' microplate concept: constraints from the Caledonian magmatic and sedimentary rocks. Annales de la Société Géologique de Belgique 114: 117-139.

André, L. \& Deutsch, S., 1985. Very low-grade metamorphic Sr isotopic resettings of magmatic rocks and minerals: evidence for a late Givetian strike-slip division of the Brabant Massif, Belgium. Journal of the Geological Society of London 142: 911-923.

André, L., Hertogen, J. \& Deutsch, S., 1986. Ordovician-Silurian magmatic provinces in Belgium and the Caledonian orogeny in middle Europe. Geology 14: 879-882.

Arthaud, F. \& Matte, P., 1977. Late Paleozoic strike-slip faulting in southern Europe and northern Africa: results of a right-lateral shear zone between the Appalachians and the Urals. Geological Society of America Bulletin 88: 1305-1320.

Bless, M.J.M., Bouckaert, J. \& Paproth, E., 1983. Recent exploration around the Brabant Massif in Belgium, The Netherlands and the Federal Republic of Germany. Geologie en Mijnbouw 62: 51-62

Bredewout, J.W., 1997. The character of the Erkelenz intrusive as derived from geophysical data. Geologie en Mijnbouw 68: 445454.

Buntebarth, G. \& Teichmüller, R., 1979. Zur Ermittlung der Paläotemperaturen im Dach des Bramscher Intrusivs aufgrund von Inkohlungsdaten. Fortschritte in den Geologie von Rheinland und Westfalen 27: 171-182.

Cottençon, A., Parant, B. \& Flacelière, G., 1975. Lower Cretaceous gas-fields in Holland. In: Woodland, A.W. (Ed.): Petroleum and the Continental Shelf of North-West Europe. Applied Science Publ. (Barking): 403-412.

Delcambre, B., 1987. Application de la typologie du zircon à la tephrostratigraphie du Westphalien $\mathrm{C}$ de la Belgique et des régions limitrophes. Bulletin de la Société Belge de Géologie 96: 129-136.

Dixon, J.E., Fitton, J.G. \& Frost, R.T.C., 1981. The tectonic significance of post-Carboniferous igneous activity in the North Sea Basin. In: Illing, L.V. \& Hobson, G.D. (Eds): Petroleum Geology of the Continental Shelf of North-West Europe. Heyden \& Son Ltd. (London): 121-137.

Dronkers, A.J. \& Mrozek, F.J., 1991. Inverted basins of The Netherlands. First Break 9: 409-425.

Eckhart, F.-J., 1968. Vorkommen und Petrogenese spilitisierter Diabase der Rotliegenden im Weser-Ems-Gebiet. Geologisches Jahrbuch 85: 227-264.

Eckhart, F.-J., 1979. Der permische Vulkanismus Mitteleuropas. Geologisches Jahrbuch D 35: 3-84.

Eigenfeld, R.W.F. \& Eigenfeld-Mende, I., 1986. Niederländische permokarbone basische Magmatite als Fortsetzung der spilitisierten Effusiva in NW-Deutschland. Mededelingen Rijks Geologische Dienst 40 (1): 11-21.

Frost, R.T.C., Fitch, J.L. \& Miller, J.A., 1981. The age and nature of the crystaline basement of the North Sea Basin. In: Illing, L.V. \& Hobson, S.D. (Eds): Petroleum Geology of the Continental Shelf of North-West Europe. Heyden \& Son Ltd. (London): 4357.

Glennie, K.W., 1986. Development of N.W. Europe's Southerm Permian Gas Basin. Geological Society Special Publication 23: 3-22.

Glennie, K.W., 1995. Permian and Triassic rifting in northwest Europe. Geological Society Special Publication 91: 1-5.

Gradstein, F.M. \& Ogg, J., 1996. A Phanerozoic time scale. Episodes 19: 3-5.

Grünhagen, H., 1981. Zur Verbreitung der Trachyttufe des Siebengebirges. Fortschritte in den Geologie von Rheinland und Westfalen 29: 59-72.

Harrison, R.K., Snelling, N.J., Merriman, R.J., Morgan, G.E. \& Goode, A.J.J., 1977. The Wolf Rock, Cornwall: new chemical, isotopic age and palaeomagnetic data. Geological Magazine 114: 249-264.

Harrison, R.K., Jeans, C.V. \& Merriman, R.J., 1979. Mesozoic igneous rocks, hydrothermal mineralisation and volcanogenic 
sediments in Britain and adjacent regions. Bulletin of the Geological Survey of Great Britain 70: 57-69.

Herngreen, G.F.W., Smit, R. \& Wong, T.E., 1991. Stratigraphy and tectonics of the Vlieland Basin, the Netherlands. Special Publication of the European Association of Petroleum Geoscientists 1: 175-192.

Jacqué, M. \& Thouvenin, J., 1975. Lower Tertiary tuffs and volcanic activity in the North Sea. In: Woodward, A.W. (Ed.): Petroleum and the Continental Shelf of North-West Europe, Vol. 1. Applied Science Publ. (Barking): 455-465.

Kettel, D., 1983. The East Groningen Massif - detection of an intrusive body by means of coalification. Geologie en Mijnbouw 62: 203-210.

Kimpe, W.F.M., 1953. Doleritic and gabbroic intrusives in the Autunian (Lower Permian) of the boring Wanneperveen I, Eastern Netherlands. Geologie en Mijnbouw 15: 57-65.

Kimpe, W.F.M., 1966. Occurrence, development and distribution of Upper Carboniferous tonsteins in the paralic West German and Dutch coalfields and their use as stratigraphic marker horizons. Mededelingen van de Geologische Stichting new. ser. 18: 3-10.

Knott, S.D., Burchell, M.T., Jolley, E.J. \& Fraser, A.J., 1993. Mesozoic to Cenozoic reconstructions of the North Atlantic and hydrocarbon plays of the Atlantic margins. In: Parker, J.R. (Ed.): Petroleum Geology of Northwest Europe. The Geological Society (London): 953-974.

Kuijper, R.P., 1991. Petrology of a dolerite in Netherlands offshore well G/17-2. Scripta Geologica 97: 33-46.

Lippolt, H.J., Hess, J.C. \& Burger, K., 1984. Isotopische Alter von pyroklastischen Sanidinen aus Kaolin-Kohlentonsteinen als Korrelationsmarken für das mitteleuropäische Oberkarbon. Fortschritte in den Geologie von Rheinland und Westfalen 32: 119-150.

Marx, J., Huebscher, H.-D., Hoth, K., Korich, D., \& Kramer, W., 1995. Vulkanostratigraphie und Geochemie der Erupkomplexe. In: Plein, E. (Ed.): Stratigraphie von Deutschland I: Norddeutsches Rotliegendbecken: Rotliegend-Monographie Teil II. Courier Forschungs-Institut Senckenberg 183: 54-83.

Odin, G.S., 1994. Geological time scale (1994). Comptes Rendus de l'Académie des Sciences (Paris) 2 318: 59-71.

Pacey, N.R., 1984. Bentonites in the Chalk of central eastern England and their relation to the opening of the north-east Atlantic. Earth and Planetary Science Letters 67: 48-60.

Perrot, J. \& van der Poel, A.B., 1987. Zuidwal - a Neocomian gas field. In: Brooks, J. \& Glennie, K. (Eds): Petroleum Geology of North West Europe. Graham \& Trotman (London): 325-335.

Rijkers, R.H.B. \& Geluk, M.C., 1996. Sedimentary and structural history of the Texel-IJsselmeer High, the Netherlands. In: Rondeel, H.E., Batjes, D.A.J. \& Nieuwenhuijs, W.H. (Eds): Geology of Gas and Oil under the Netherlands. Kluwer (Dordrecht): 265-284.

Ritchie, J.D., Gatliff, R.W., Richards, P.C., 1999. Early Tertiary magmatism in the offshore NW UK margin and surrounds. In: Fleet, A.J. \& Boldy, S.A.R. (Eds): Petroleum Geology of Northwest Europe. The Geological Society (London): 573-584.

Sissingh, W., 1986. Stratigraphic Reference Data Book of the Netherlands. Internal NAM Report (Assen).

Stadler, G. \& Teichmüller, R., 1971. Zusammenfassender Überblick über die Entwicklung des Bramscher Massivs und des Niedersächsischen Tektogens. Fortschritte in den Geologie von Rheinland und Westfalen 18: 547-564.

Teichmüller, M. \& Teichmüller, R., 1971. Inkohlung. Fortschritte in den Geologie von Rheinland und Westfalen 19: 69-72.

Tesch, P., 1925. Over een intrusie in het Carboon van Oostelijk Gelderland. Geologisch-Mijnbouwkundig Genootschap voor
Nederland en Koloniën, Verslagen van de Geologische Sectie: 95.

Tesch, P., 1928. On the occurrence of igneous rocks in the Dutch Carboniferous. 1e Congres pour l'Avancement des Études de Stratigrafie Carbonifère, Compte Rendu: 731-732.

Tesch, P. \& van Voorthuysen, J.H., 1944. Nog drie intrusies in het Carboon van Oost-Gelderland. Geologie en Mijnbouw 5: 56-57.

Thiadens, A.A., 1963. The Palaeozoic of the Netherlands. Verhandelingen van Nederlands Koninklijk Geologisch Mijnbouwkundig Genootschap, Geologische Serie 21 (2): 9-28.

Tomkeieff, S. \& Tesch, P., 1931. On a dolerite in the Dutch Carboniferous. Geological Magazine 68: 232-236.

Underhill., J.R. \& Partington, M.A., 1993. Jurassic thermal doming and deflation in the North Sea: implications of the sequence stratigraphic evidence. In: Parker, J.R. (Ed.): Petroleum geology of Northwest Europe. The Geological Society (London): 337345.

Valeton, I., 1960. Vulkanische Tuffiteinlagerung in der nordwestdeutschen Oberkreide. Mitteilungen aus dem Geologischen Staatsinstitut in Hamburg 29: 26-41.

Van Adrichem Boogaert, H.A. \& Kouwe, W.F.P. (comps), 1993. Stratigraphic nomenclature of the Netherlands, revision and update by RGD and NOGEPA. Mededelingen Rijks Geologische Dienst 50.

Van Bergen, M.J. \& Sissingh, W., in press.Magmatic expression of the North-West European rifting history in the Netherlands. In: Wong, Th.E., Batjes, D.A.J. \& de Jager, J. (Eds): Geology of the Netherlands. Royal Netherlands Academy of Arts and Sciences (Amsterdam).

Van den Bosch, W.J., 1983. The Harlingen field, the only gas field in the Upper Cretaceous of the Netherlands. Geologie en Mijnbouw 62: 145-156.

Van der Sijp, J.W.C.M., 1953. Intrusive rocks in the Berkel well. Geologie en Mijnbouw 15: 65-66.

Van Montfrans, H.M. \& Mot, E., 1984. Mogelijkheden voor de winning van aardwarmte in Nederland. In: Mot, E. (Ed): Verslag van het Nationaal Onderzoekprogramma Aardwarmte en Warmteopslag 1979-1984 (NOA I). Project Bureau Energieonderzooek (Apeldoorn): 8-14.

Van Voorthuysen, J.H., 1944. Hoornblendediabaas-intrusie in het Wealden van Oost-nederland. Geologie en Mijnbouw 5: 24-26.

Van Weelden, A., 1957. History of gravity observations in The Netherlands. Verhandelingen van het Koninklijk Nederlandsch Geologisch-Mijnbouwkundig Genootschap, Geologische Serie 18: 305-308.

Van Wees, J.-D., Stephenson, R.A., Ziegler, P.A., Bayer. U., McCann, T., Dadlez, R., Gaupp, R., Narkiewicz, M., Bitzer, F. \& Scheck, M., 2000. On the origin of the Southern Permian Basin, Central Europe. Marine and Petroleum Geology 17: 43-59.

Van Wijhe, D.H., 1987. Structural evolution of inverted basins in the Dutch offshore. Tectonophysics 137: 171-219.

Veldkamp, J., 1951. Geomagnetic anomalies in The Netherlands. Geologie en Mijnbouw 13: 218-223.

Vercoutere, C. \& van den Haute, P., 1993. Post-Palaeozoic cooling and uplift of the Brabant Massif as revealed by appatite fission track analysis. Geological Magazine 130: 639-646.

Vielzeuf, D. \& Kornprobst, J., 1984. Crustal splitting and the emplacement of Pyrenean lherzolites and granulites. Earth and Planetary Science Letters 67: 87-96.

Walter, R., 1980. Lower Paleozoic paleogeography of the Brabant Massif and its southern adjoining areas. Mededelingen Rijks Geologische Dienst 32 (2): 14-25.

Ziegler, P.A., 1990. Geological Atlas of Western and Central Europe. 2nd Ed. Shell Internationale Petroleum Mij. B.V. (The Hague): 239 pp. 
Zimmerle, W., 1993. On the lithology and provenance of the Rupelian Boom Clay in northern Belgium, a volcaniclastic deposit. Bulletin de la Société Belge de Géologie 102: 91-103. 